\title{
Sosyal Pazarlama ve Gönüllülük: Kan Bağışı Üzerine Bir Araştırma1 (Social Marketing and Volunteering: A Research on Blood Donation)
}

\section{Mustafa KAPLAN iD a}

a Çanakkale Onsekiz Mart Üniversitesi, Siyasal Bilgiler Fakültesi, Çanakkale, Türkiye. mustafakaplan@comu.edu.tr

\begin{tabular}{|c|c|}
\hline MAKALE BİLGİSİ & ÖZET \\
\hline Anahtar Kelimeler: & $\begin{array}{l}\text { Amaç - Bu çalışmanın temel amacı; tutum, algılanan davranışsal kontrol, öznel norm, altruizm ile } \\
\text { gönüllülük arasındaki ilişkileri ve sosyal pazarlama faaliyetlerinin algılanan etkinliğinin bu } \\
\text { değişkenler üzerindeki etkilerini belirlemeye çalışmaktır. }\end{array}$ \\
\hline $\begin{array}{l}\text { Gönüllülük } \\
\text { Planlı Davranış Teorisi }\end{array}$ & $\begin{array}{l}\text { Yöntem - Araştırmanın verileri yapılandırılmış anket formu vasıtasıyla toplamda } 399 \text { kişiden yüz } \\
\text { yüze toplanmıştır. Anketler kan bağışı yapmaya uygun kişilere uygulanmıştır. Elde edilen bu } \\
\text { verilerin SPSS } 20 \text { ve Lisrel } 8.80 \text { paket programları ile analizleri gerçekleştirilmiş ve raporlanmıştır. }\end{array}$ \\
\hline $\begin{array}{l}\text { Gönderilme Tarihi } 11 \text { Temmuz } \\
2020 \\
\text { Revizyon Tarihi } 29 \text { Ekim } 2020 \\
\text { Kabul Tarihi } 8 \text { Kasım } 2020\end{array}$ & $\begin{array}{l}\text { Bulgular - Yapılan analizler sonucunda; sosyal pazarlama faaliyetlerinin algılanan etkinliğinin } \\
\text { tutum, algılanan davranışsal kontrol, öznel norm ve altruizm üzerinde anlamlı bir etkisinin olduğu } \\
\text { tespit edilmiştir. Ayrıca sosyal pazarlama faaliyetlerinin algılanan etkinliğinin gönüllülük niyeti } \\
\text { üzerinde de anlamlı bir etkisinin olduğu bulgusuna da ulaşılmıştı. Bunların yanı sıra öznel norm } \\
\text { ve algılanan davranışsal kontrolün gönüllük niyeti üzerinde anlamlı bir etkisi olduğu tespit } \\
\text { edilmiştir. }\end{array}$ \\
\hline Araştırma Makalesi & $\begin{array}{l}\text { Tartışma - Kan bağışı gibi toplumsal açıdan son derece önemli ve süreklilik arz eden bir konudaki } \\
\text { faaliyetlerin bireylere etki etmesi son derece önemli olmaktadır. Kan bağışı konusunda yapılan } \\
\text { faaliyetler, kan bağışına ihtiyacı olan bireyleri ve kan bağışı konusunda gönüllü bireyleri ortak } \\
\text { noktada buluşturmaktadır. Dolayısıyla yapılan faaliyetlerin toplumsal bir fayda sağladığı } \\
\text { görülmektedir. }\end{array}$ \\
\hline
\end{tabular}

\begin{tabular}{|c|c|}
\hline ARTICLE INFO & ABSTRACT \\
\hline Keywords: & Purpose - The main aim of the study is to try to determine the relationship between attitudes, \\
\hline Social Marketing & subjective norm, perceived behavioral control, altruism and intention of volunteering and perceived \\
\hline Volunteering & \\
\hline $\begin{array}{l}\text { Theory of the Planned } \\
\text { Behavior }\end{array}$ & $\begin{array}{l}\text { Design/methodology/approach - Data of this study were collected face to face from } 399 \text { people via } \\
\text { structured questionnaires. The questionnaires were administrated to people who have eligible to } \\
\text { blood donate. The obtained data were analyzed and reported by SPSS } 20 \text { and LISREL } 8.80 \text { package } \\
\text { programs. }\end{array}$ \\
\hline Received 11 July 2020 & Findings - As a result of these analyzes, it is determined that the perceived effectiveness of social \\
\hline Revised 29 October 2020 & marketing activities has a significant effect on attitudes, subjective norm, perceived behavioral \\
\hline Accepted 8 November 2020 & $\begin{array}{l}\text { control and altruism. It is also found that the perceived effectiveness of social marketing activities } \\
\text { has a significant effect on the intention of volunteering. Furthermore, it is determined that the } \\
\text { subjective norm and perceived behavioral control have a significant effect on intention of } \\
\text { volunteering. }\end{array}$ \\
\hline Research Article & $\begin{array}{l}\text { Discussion - Impact to individuals and activities in socially very important issues, sustainable } \\
\text { development, such as blood donation is extremely important. The actions taken regarding blood } \\
\text { donation, meet a common point volunteers and who need blood donation. Therefore, it seems that } \\
\text { the activities provided have a social benefit. }\end{array}$ \\
\hline
\end{tabular}

\footnotetext{
${ }^{1}$ Bu çalışma Çanakkale Onsekiz Mart Üniversitesi Sosyal Bilimler Enstitüsü İşletme Anabilim Dalı'nda Mustafa Kaplan tarafından tamamlanan “Sosyal Pazarlama Faaliyetlerinin Gönüllülük Davranışlarına Etkisi: Türk Kızılayı ve Kan Bağışı Üzerine Bir Araştırma” adlı doktora tezinden türetilmiştir.
} 


\section{Gíríş}

Örgütler, ürünlerini satarak kâr sağlayıp büyüme ve yine bu döngü içinde daha fazla kâr elde etme hedeflerinin yanı sıra kaçınılmaz olarak toplumsal sorunlara da çeşitli çözümler ortaya koymak durumundadır. Örgütlerin bu çözümlerin uygulanmasına yönelik destek olma işlevleri ile sosyal pazarlama kavramı ön plana çıkmaktadır. Wiebe 1952 yılında “Neden sabun sattığınız gibi kardeşliği de satmıyorsunuz?" sorusu ile toplumsal sorunların çözümü için ticari pazarlama yöntemlerinin kullanabileceği fikrini ortaya atmıştır. İlk olarak bu fikirden yola çıkarak sosyal pazarlama Kotler ve Zaltman tarafından ortaya konmuş ve tanımlanmıştır. Kotler ve Zaltman sosyal pazarlamayı; sosyal fikirlerin kabul edilebilirliğini etkilemek amacıyla iletişim, fiyatlama, ürün planlaması, dağıtım ve pazarlama araştırmalarının tasarlanması, uygulanması ve kontrolüdür şeklinde tanımlamaktadır (Kotler ve Zalman, 1971: 5). Bu açıdan bakıldığında sosyal pazarlama, sosyal konulardaki toplumsal problemlerin (organ bağışı, kan bağışı, sigara tüketimi, sağlık sorunları vb.) çözümü amacıyla pazarlama araçlarının kullanılması olarak da görülebilmektedir.

Pazarlamanın sosyal yönünün ön plana çıktığı bu noktada; tek kaynağı insan olan, alternatifi bulunmayan biyolojik bir madde olarak kabul edilen kan ve bunun yanı sıra sürekli ve aralıksız olarak ihtiyaç duyulan kan bağışı konusu da üstünde durulması gereken önemli bir konu olmaktadır. Dahası kan bağışı yapmaya uygun kişilerin kan bağışlama oranının düşük kalması konuyu daha da önemli hale getirmektedir (France vd., 2007: 1006).

Türk Kızılayı'nın verilerine göre Türkiye'de her dört saniyede bir ünite kana ihtiyaç duyulmaktadır, yani siz bu cümleyi okurken yaklaşık bir ünitelik kan ihtiyacı ortaya çıkmaktadır. Yine Türk Kızılayı'nın verilerine göre her bir kan bağışı üç kişinin hayatını kurtarmaktadır. Bu açıdan bakıldığında kan bağışı hem Türkiye'de hem de dünyada sürekli ihtiyaç nedeniyle önemini devamlı olarak koruyan toplumsal konulardan birisi olmaktadır. Bu çerçevede özellikle Türk Kızılayı'nın yürüttügü bilinçlendirme kampanyaları, kamu spotları, bağış toplama kampanyaları gibi faaliyetler ve bunun yanı sıra diğer kuruluşların yürüttüğü organizasyonlar olsa da gelişmiş ülkelerde gönüllü kan bağışlarının nüfusa oranı \%5'e ulaşırken bu oranın Türkiye'de \%3,6 civarında olmaktadır. Kan bağışı konsuundaki bu yetersizlik de önemli bir sorun oluşturmaktadır. Kan bağışı konusundaki sürekli ihtiyaç haline bağış konusundaki yetersizlik de eklenince konu daha da önemli hale gelmektedir.

$\mathrm{Bu}$ çalışmanın amacı da bu bağlamda sosyal pazarlama faaliyetlerinin algılanan etkinliğinin kan bağışı gönüllülüğü ile ilişkisini araştırmaktır. Yapılan çalışmada Planlı Davranış Teorisi (PDT) çerçevesinde sosyal pazarlama faaliyetlerinin algılanan etkinliği, tutum, algılanan davranışsal kontrol, öznel norm, altruizm ve bireylerin gönüllülük niyeti arasındaki ilişki incelenmektedir. Bu amaçla PDT temelinde bir araştırma modeli oluşturulmuştur. Bu model, yapılandırılmış anket yoluyla elde edilen verilerle test edilmektedir. Yapılan bu çalışmada ayrıca gelecekte yapılacak olan benzer faaliyetlere katkı sağlanması hedeflenmektedir.

\section{LİTERATÜR İNCELEMESI}

Pazarlama kavramı toplumsal ihtiyaçlar ile o toplumunun bu ihtiyaçlarına verdiği ya da vereceği tepkiler arasında bir köprü görevi görmektedir. Bu açıdan pazarlama, işletmelerin toplum ile arasındaki bağı kuran ve iki tarafa da fayda sağlayacak bir ilişkinin temelini oluşturan fonksiyondur (Tek ve Özgül, 2013: 1). Bu bağlamda pazarlama anlayışının geçmişten günümüze farklı dönemlerden geçtiğini söylemek mümkündür. Üretim anlayışından başlayarak satış anlayışı ve pazarlama anlayışına ulaşan bu süreç, işletmelerin topluma karşı sorumluluklarının ön plana çıkmasıyla beraber toplumsal pazarlama anlayışına doğru gelişim göstermiştir (Mucuk, 2014: 7). Amerikan Pazarlamacılar Derneği de (AMA) gelişen bu süreç doğrultusunda 2017 yılında pazarlamayı; bireysel tüketiciler, kurumsal müşteriler, iş ortakları ve genel olarak topluma değer yaratan, iletişim kuran, ulaştıran kurumlar kümesi ve süreçler olarak tanımlamaktadır (AMA, 2017). Bu tanımla beraber pazarlamanın anlam ve içeriğinin, işletmenin hedefleri ve toplumla ilişkisi kurularak da incelenmesi mümkündür. İşletmelerin temel amacı kar elde etmek ve dolayısıyla faaliyetlerinin sürekliliğini sağlamaktır. İşletmelerin bu temel amaçlarına ulaşırken yapması gereken ise müşterilerine fayda yaratmasıdır. Bu yaratılan faydanın toplumun diğer kesimlerine yönelik bir zarar sağlamaması ise toplumsal pazarlama anlayışının gerekliliği olmaktadır. Burada konuyla ilgili belirtilmesi gereken bir diğer nokta ise toplumsal fayda ile sosyal faydanın farklı kavramlar olduğudur. Toplumsal fayda işletmelerin toplumsal pazarlama anlayışı içerisinde yerine getirmesi gereken bir sorumluluktur. Öte yandan sosyal fayda ise 
işletmenin faaliyet alanını kapsamasa bile kâr amacı gütmeden bu konuda değer yaratmaya çalıştığı faaliyetlerdir (Tek ve Özgül, 2013: 3-4).

İşletmelerin sosyal alanlardaki sorumluluklarıyla ilgili gelişmelere paralel olarak, işletmelerin vitrini olan pazarlama faaliyetleri açısından sosyal konulardaki alanların daha hızlı bir şekilde genişlediği görülmektedir. $\mathrm{Bu}$ gelişmeler sonucunda pazarlamacılar, tüketicileri daha ciddi şekilde yanına çekme ve onları kazanma zorunluluğunda kalmaktadır. İşletmeler kendi refahları yanında tüketicilerin ve genel olarak toplumun refahını da düşünmek ve bunlara hizmet etme amacını benimseme durumunda kalmıştır. İşletmeleri bu şekilde bir amacı benimsemeye iten şartların başında daha önce de söylendiği gibi toplumu daha ciddi şekilde yanına çekme ihtiyacının ortaya çıkmasıdır (Torlak, 2007: 66).

Sosyal pazarlama faaliyetleri, daha geniş ölçekli olan sosyal sorumluluk faaliyetlerinin bir parçası olarak kabul edilebilmektedir. Bu açıdan sosyal pazarlama faaliyetlerinin en ayırt edici yönü; sosyal açıdan faydalı davranışların teşvik edilmesi ve bu konulara odaklanmasıdır (Bloom vd., 1995: 10). Kavramsal olarak sosyal pazarlama ilkin Kotler ve Zaltman (1971) tarafından "Sosyal fikirlerin kabul edilebilirliğini etkilemek amacıyla iletişim, fiyatlama, ürün planlaması, dağıtım ve pazarlama araştırmalarının tasarlanması, uygulanması ve kontrolüdür." şeklinde tanımlanmaktadır (Kotler ve Zalman, 1971: 5).

Sosyal pazarlama kavramının geçmişi çok eski olmamakla beraber bu kavramın kökenleri, Wiebe, Mendelsohn, Lazarsfeld, Merton, Hyman ve Sheatsley'in 1940 ve 1950'li yıllarda sosyal psikoloji, kitlesel iletişim, reklam ve halkla ilişkiler çerçevesinde yaptıkları çalışmalara dayanmaktadır. Ancak yapılan bu çalışmaları yapan bilim adamlarından hiçbirisi pazarlama kökeninden gelmemekteydi (Rothschild, 1997: 308). Pazarlama kökenli bilim adamları çerçevesinde sosyal pazarlama kavramı ilk defa Kotler ve Zaltman (1971) tarafından ortaya konmuştur. Bu şekilde "Sosyal Pazarlama" ilk defa net olarak kavramsallaşmaktadır. Pazarlamanın toplumsal sorunlar üzerindeki etkileri üzerine yapılan tartışmalar 1960'ların sonundan itibaren ciddi şekilde tartışılmaya başlanmıştır. Bununla beraber 70'li yıllarda pazarlama dergilerinde konuyla ilgili yapılan çalışmalar ivme kazanmıştır. Konuyla ilgili ortaya atılan fikirler pazarlamanın toplumsal ihtiyaçları karşılayacak şekilde nasıl genişleme gerektiği çerçevesinde oluşmuştur (Ling vd.,1992: 343).

Çalışmanın teorik altyapısını oluşturması itibariyle bireylerin bir davranışını nasıl gerçekleştirdiğini anlamaya çalışan PDT'yi açıklamaya çalı̧̧mak da çalışmanın amacı ve konusunu ortaya koyma açısından faydalı olacaktır. PDT, gerekçelendirilmiş eylem bir uzantısı olarak ifade edilmektedir (Ajzen, 1991: 181). PDT, belirli bir çerçevede gerçekleşen insan davranışlarını açıklamak ve tahmin etmek amacıyla geliştirilmiş bir teoridir. Psikoloji alanında geliştirilmiş bir teori olmasının yanı sıra, PDT birçok farklı disiplin alanındaki davranışları açıklamak için kullanılmıştır (Öztürk vd., 2015: 145).

\subsection{Tutum}

Psikoloji literatüründe davranış ile ilgili birçok çalışmada incelenmiş olan "tutum" kavramı, Baron ve Byrne (1977) tarafından, oldukça organize olmuş, diğer insanları, grupları, fikirleri, ülkenin diğer yörelerini ya da nesneleri konu edinen uzun süreli duygu, inanç ve davranış eğilimleri olarak tanımlanmaktadır (Cüceloğlu, 2007: 521). Pazarlama açısından ise tutum; bir ürünü değerlendiren kişinin o ürüne ilişkin geliştirdiği olumlu veya olumsuz eğilimdir. Pazarlama literatüründe tutum genel olarak üç boyutuyla ele alınan bir olgu olarak görülmektedir. Bu boyutlar bilişsel, duygusal ve davranışsal boyut olarak ifade edilmektedir. Bir bireyin kişi, nesne ya da markaya karşı tutumundan bahsedilirken, aslında bireyin söz konusu nesne veya kişiye karşı içinde oluşturmuş olduğu değerlendirme eğiliminin bilişsel, duygusal ve davranışsal bileşenlerinden bahsedilmektedir (İslamoğlu ve Altunışık, 2013: 134). Bireylerin bir konuyla ilgili tutumlarının o konuyla ilgili davranışı göstermelerindeki niyete etkisi birçok çalışmanın konusu olmaktadır. Kan bağışına yönelik olarak literatürde yapılan birçok çalışmada tutumun niyeti etkilediği tespit edilmektedir (Argan, 2016; Faqah vd., 2015; Bagot vd., 2015; Mirutse vd., 2014; Bednall vd., 2013; Holdershaw vd., 2011; Merav ve Lena, 2010; Masser vd., 2009; McMahon ve Byrne, 2008; Armitage ve Conner, 2001).

\section{2. Öznel Norm}

Öznel norm Ajzen (1991: 188) tarafından bireyin davranışı gerçekleştirmesi ya da gerçekleştirmemesi durumunda karşılaşacağı sosyal baskı olarak tanımlamaktadır. Diğer bir deyişle davranışı gösterecek olan kişi için önemli olan kişilerin, kurum veya kuruluşların ifade edilen davranışı gerçekleştirme ya da gerçekleştirmeme konusunda beklentilerdir. Bunların yanı sıra öznel normlar bireylerin kendilerine ait özel 
inanç, yargı, değer gibi özgür iradeyi ortaya koyan seçim haklarından oluşmalarının yanı sıra bireyin içinde yaşadığı toplumun gelenek, sosyal adetleri, baskı ve kuralları çerçevesinde oluşmuş değerler olarak tanımlanmaktadır (Öztürk vd., 2015: 146). PDT çerçevesinde, öznel normlar, normatif inançlar ve bireyin bu normlara uyma motivasyonlarına göre oluştuğu belirtilmektedir. Buradan hareketle öznel norm, tutumlarda olduğu gibi, inançların bir fonksiyonu olmaktadır. Fakat burada bahsi geçen inançlar davranışsal inançlardan farklılaşmakta ve diğer bireylerin veya toplulukların o bireyin herhangi bir davranışı ortaya koymasını bekleyip beklemediği konusunda kişinin sahip olduğu inançları ifade etmektedir (Ajzen, 1991).

\subsection{Algılanan Davranışsal Kontrol}

PDT modeline daha sonradan eklenen algılanan davranışsal kontrol, bireyin herhangi bir davranışı uygulamasının kendi kontrolünde olup olmadığı yönünde yetenekleri ve fırsatlarıyla ilgili algılamalarıdır. Algılanan davranışsal kontrol, davranışı kolaylaştıran ya da engelleyen etkenlerin ortaya çıkma aralıklarına göre değerlendirilmektedir. Bir başka deyişle bir birey; bir konu hakkında ne kadar fazla olanak ve kaynağa sahipse ve bu konu hakkında ne kadar az engel ile karşı karşıya kalıyorsa bireyin davranış üzerinde algılanan kontrolü o kadar büyük olmaktadır (Kocagöz, 2010: 29). Genel bir kabul olarak; bir davranışı yapmaya yönelik olarak bireyin ne kadar olumlu tutum, öznel norm ve güçlü bir davranışsal kontrolü varsa, söz konusu davranışı yerine getirme niyeti de o kadar yüksek olmaktadır. Bunun yanı sıra bireyin davranış üzerinde yeterli düzeyde kontrolü olduğu durumlarda niyeti davranışa dönüştürdüğü de ifade edilmektedir (Ajzen, 2008: 538). Literatürde yapılan çalışmalarda algılanan davranışsal kontrolün niyet üzerinde bir belirleyici olduğu bulgulanmakta, dahası davranışın isteğe bağlı olarak tam kontrol altında olmadığı durumlarda özellikle geçerli olduğu ifade edilmektedir (Armitage ve Conner, 2001; Madden vd., 1992).

\subsection{Niyet}

PDT temelinde bireylerin davranışlarını açıklamaya yöneliktir. Dolayısıyla niyet, davranışı açıklamada hem gerekçelendirilmiş eylem teorisinde hem de PDT'de davranışın açıklanmasında aracılık rolü olan bir değişkendir (Ajzen, 1991). Bahsi geçen teorilerde niyet, davranışın en yakın tahmincisi olarak belirtilmekte ve bu değişken diğer değişkenlerle davranış arasında bir bağ kurmaktadır. Niyet, kişilerin bir davranışı gerçekleştirme ya da gerçekleştirmeme doğrultusundaki eğilimleri olarak belirtilmektedir. Ajzen (1991) ise niyeti, bireyin bir davranışı gerçekleştirmek için ortaya koyduğu arzu seviyesi ve ortaya koymayı planladığı çabanın yoğunluğu olarak tanımlamaktadır. Niyet, gerekçelendirilmiş eylem teorisinde tutum ve öznel norm ile davranış arasında bir aracı değişken olurken, PDT'de tutum, öznel norm ve algılanan davranışsal kontrol ile davranış arasındaki aracı değişken olmaktadır (Kocagöz, 2010: 33). Konuyla ilgili olarak bireyin bir davranışı gerçekleştirmesinden önce o davranışa yönelik niyetinin oluştuğu ve niyet ile davranış arasında güçlü bir bağ bulunduğu belirtilmektedir. Kan bağışına yönelik olarak literatürde yapılan birçok çalışmada da buna benzer sonuçların elde edildiği görülmektedir (Argan, 2016; Faqah vd., 2015; Bagot vd., 2015; Mirutse vd., 2014; Bednall vd., 2013; Holdershaw vd., 2011; Merav ve Lena, 2010; Masser vd., 2009; McMahon ve Byrne, 2008; Armitage ve Conner, 2001).

\subsection{Altruizm}

Sosyal ilişkilerde karşımıza çıkan ve bireyler arası ilişkilerin doğru bir şekilde sürdürülmesini kolaylaştıran en önemli faktörlerden biri altruizmdir. Sosyal psikoloji alanındaki araştırmalarına bu açıdan konu olan altruizm, bireylerin hiçbir çıkar beklentisi olmadan, sadece diğer insanların faydaları için yaptıkları bütün davranışlar şeklinde tanımlanabilmektedir (Tekeş ve Hasta, 2015: 57). Altruizm ve kan bağışı arasındaki ilişki çerçevesinde yapılan araştırmalarda altruizmin yanı sıra aile ve sosyal etkilerin de kan bağışlama davranışına etki ettikleri tespit edilmektedir (Alessandirini, 2007; Ferguson vd., 2012; Hablemitoğlu vd., 2010; Trimmel vd., 2005; Wildman ve Hollingsworth, 2009).

\section{YÖNTEM}

\subsection{Araştırma Modeli ve Hipotezler}

$\mathrm{Bu}$ araştırmada kullanılan model, sosyal pazarlama faaliyetlerinin algılanan etkinliğinin tutum, algılanan davranışsal kontrol, öznel norm, altruizm ve niyeti etkilediğini ileri sürmektedir. Bunun yanı sıra tutum, algılanan davranışsal kontol, öznel norm ve altruizm değişkenlerinin de niyet üzerinde etkisi olduğunu ileri sürmektedir. Öte yandan bu bölümde araştırma modelinde yer alan değişkenler arası ilişkilere yer verilmiştir. 


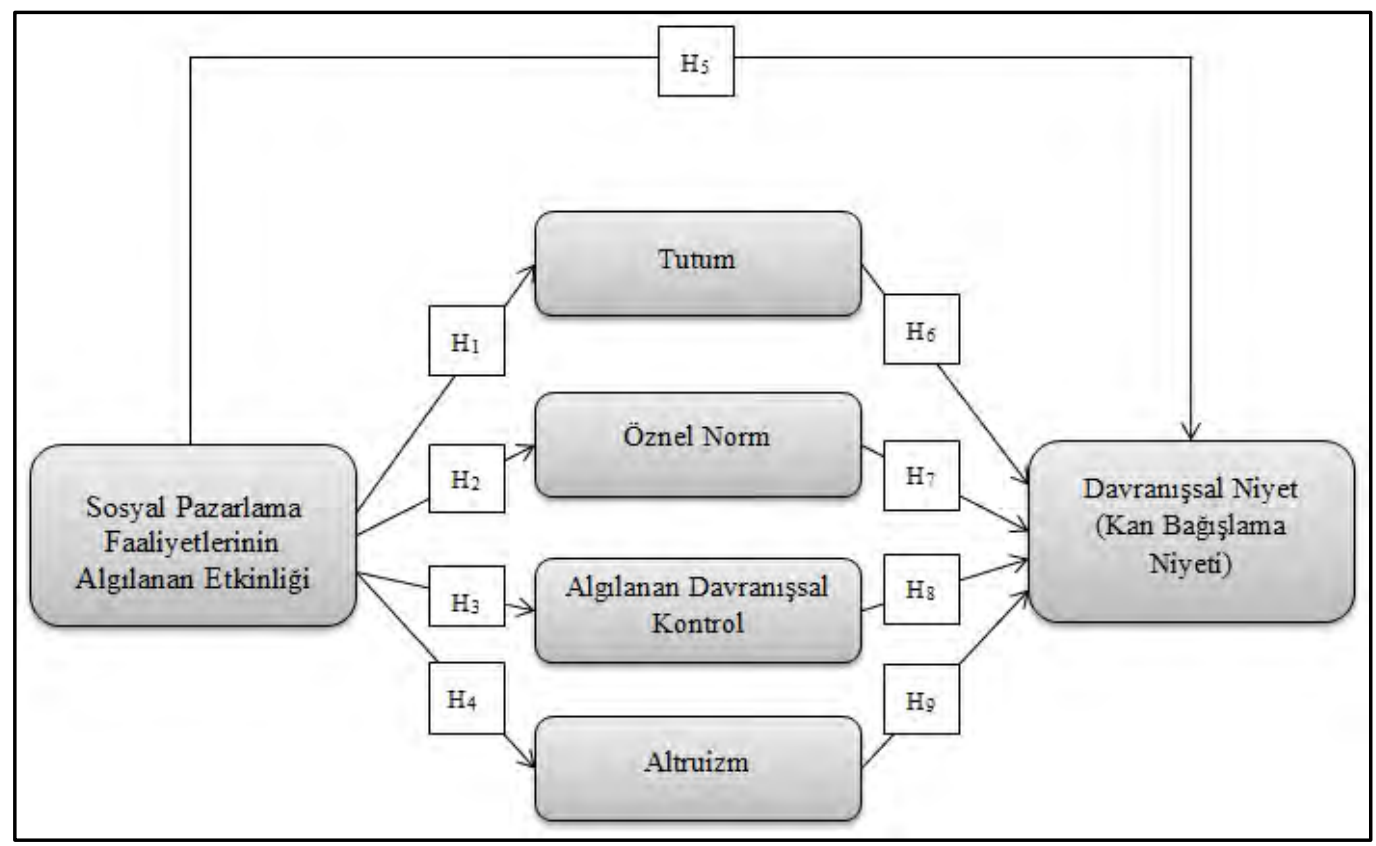

Şekil 1. Araştırma Modeli

Kan bağışının sürekli ve aralıksız olarak ihtiyaç duyulan bir gereksinim olması, onu üstünde önemle durulması gereken bir konu haline getirmektedir. Kan bağışı yapmaya uygun kişilerin kan bağışlama oranının düşük kalması, dahası; bir kere kan bağışı yapan bireylerin bir daha kan bağışı yapmaması gibi durumlar kan bağışı konusunun bireylerin nezdinde devamlı canlı halde tutulması gereken bir olgu haline getirmektedir (France vd., 2007: 1006).

Sosyal pazarlamanın amacı, inançsızlığı, bir inanca dönüştürmek, bir inancı bir tutum ya da tutum içinde bir değere dönüştürmektir. Bu bağlamda, kabul sürecini, kan bağışı davranışını öğrenme-hissetme çerçevesinde açıklamaya çalışan farklı modeller tanımlanmıştır (Kotler ve Andreasen, 1991). Bu sebeple, kan bağışı konusundaki tutumun bilişsel ve duygusal faktörleri, bazı bireylerin kan bağışı konusundaki olumlu eğilimlerini açıklama konusunda belirleyici olmaktadır (Giles ve Cairns, 1995). Bireylerin kan bağışı konusundaki bilgisi arttıkça kan bağışlama eğilimleri arttığından dolayı bilgi kan bağışı davranışını benimseme sürecinin başlangıç noktası haline gelmektedir (Pagliariccio vd., 2003; Belda Suarez vd., 2004; Zaller vd., 2005). Bireylerin kan bağışı yapmamaların başlıca sebeplerinden biri bağış konusundaki bilgi eksikliğidir ve bu eksikliğin bireyleri kan bağışlama konusunda isteksizliğe götüren bir değişken olduğu düşünülmektedir (Ownby vd., 1999; Pagliariccio vd., 2003).

Bireyler bir konuyla ilgili davranış kararı verirken bilişsel işlevlerini kullanarak süreci başlattıklarından ve kararları temelde rasyonel olduğu için konuyla ilgili ayrıntılı bilgi istemektedirler. Dolayısıyla bu durumlarda konuyla ilgili iletilen mesajların bilgilendirici içerikte olması önemli olmaktadır (Petty ve Caciopo, 1986; Beerli-Palacio ve Martin-Santana, 2009).

Arzulanan sosyal davranışların benimsenmesindeki öneminden dolayı kan bağışı motivasyonları birçok araştırmanın konusu olmuştur. Son yıllarda yapılan pek çok eser altruizmi kan bağışında bulunmanın başlıca nedenlerinden biri olarak göstermektedir (Fernandez Montoya vd., 1998; Glynn, 2002; Garcia Gutierrez vd., 2003; Misje vd., 2005; Zaller vd., 2005; Javadzadeh Shahshahani vd., 2006). Bağışçılar, kan bağışçısı olmanın kimliğin önemli bir parçası haline gelmesinden dolayı dışşal faktörlere nispeten içsel faktörlerden daha çok etkilenmektedir (Piliavin ve Callero, 1991; Piliavin, 1992; Hupfer vd., 2005). Kan bağışı, bireyin konuyla alakalı korku ve isteksizlik eğilimli tutumu içeren bir süreci içermektedir. Literatürde yapılan çalışmalarda, kan bağışı yapılmasının önünde kan alma süreci korkusunun yanı sıra birçok diğer engel bulunduğu görülmektedir (Andaleeb ve Basu, 1995; Nonis vd., 1996; Ownby vd., 1999; Zaller vd., 2005; Javadzadeh Shahshahani vd., 2006). Bahsedilen diğer engeller, fiziksel risk (hastalık bulaşması), psikolojik (korku), sosyal (ahlaki sorumluluk) ve zaman (zaman kaybı) olarak sinıflandırılabilir (Nonis vd., 1996).

Kan bağı̧̧ı eğilimini etkileyen faktörlerin belirlenmesine yönelik yapılan araştırmada bu faktörlerin, kan bağışı konusundaki sahip oldukları bilgi, kan bağışı konusundaki korkuları, bağış yapma motivasyonları, kan bağışı 
ile ilgili geçmiş deneyimleri, referans gruplarıyla bağlantıları (aile, arkadaşları, meslektaşları vb.) olduğu belirtilmektedir (Beerli-Palacio ve Martin-Santana, 2009).

Birçok araştırmacı sosyal pazarlamanın bireylerin fikirleri etkilemekle beraber bunun ötesinde tutum ve davranışları da etkileyebileceğini ifade etmektedir. Kotler ve Roberto (1989) yaptıkları bir incelemede sosyal pazarlamayı sosyal değişim kampanyasıyla belli fikirleri, tutumları, davranışları değiştirmeye yönelik organize bir çaba olarak görüldügünü belirtmektedir (Andreasen, 1994: 110). Sosyal pazarlama çerçevesinde davranış değişikliklerini ölçümlemenin içsel tutum ve inançları gözlemlemeye göre daha kolay olduğu da ifade edilmektedir (Dann, 2010: 150). Toplumsal olaylarda sosyal pazarlama bağlamında iletilen mesajın değerlendirilmesi açısından algılanan etkinlik kavramının önemi birçok araştırmada ortaya konmaktadır (Davis vd., 2016: 1). Bu araştırmaların temelinde belli bir sosyal meselede ele alınan konu ile bireylerin o konuyla ilgili reklama yönelik tutumu ile ilişkisi olacağını savunan ampirik ve teorik uygulamalar yatmaktadır (Dillard ve Peck, 2000). Bu tür sosyal olaylara yönelik bireylerin tutumları; reklamlardaki bilgilendiricilik düzeyi, algılamaları, reklamın inandırıcılı̆̆ı, güvenilirlik ve beğenilme gibi faktörlere göre değişkenlik gösterebilmektedir. Bu kavramlar genel olarak algılanan etkinlik altında gruplandırılmaktadır (Dillard ve Peck, 2000; Dillard vd., 2007; Murphy-Hoefer vd., 2008).

Sosyal pazarlama kampanyaları kapsamında yürütülen, tütün ürünleri kullanımı, alkol kullanımı, uyuşturucu kullanımı, fiziksel aktivite, HIV testi gibi konulardaki reklam faaliyetleri mesajlarının hedeflediği tutum ve davranışları etkilediği tespit edilmektedir (Alvaro vd., 2013; Davis vd., 2016; Davis vd., 2011; Dillard vd., 2007). Bireylerin kan bağışı konusundaki bilinçlerini arttırmak dolayısıyla gönüllülük motivasyonlarını yükseltmek ve tüm bunların sonucunda da kan bağışını arttırmak için konuyla ilgili farkındalığın arttırılması gerekliliği literatürde yapılan çalışmalarda üstünde durulan bir diğer konudur. Kan bağışıyla ilgili bilinç ve farkındalığın artması için etkili yöntemler olarak konuyla ilgili eğitim programlarının düzenlenmesi ve sivil toplum kuruluşlarının kitle iletişim araçlarını etkin şekilde kullanması gerektiği belirtilmektedir (Echevarria ve Garcia, 2014: 468).

Bu bilgiler doğrultusunda aşağıdaki hipotezler ileri sürülmüştür:

Hı: Sosyal pazarlama faaliyetlerinin algılanan etkinliği ile kan bağışına yönelik tutum arasında anlamlı ve pozitif yönlü bir ilişki vardır.

$\mathrm{H}_{2}$ : Sosyal pazarlama faaliyetlerinin algılanan etkinliği ile öznel norm arasında anlamlı ve pozitif yönlü bir ilişki vardır.

$\mathrm{H}_{3}$ : Sosyal pazarlama faaliyetlerinin algılanan etkinliği ile algılanan davranışsal kontrol arasında anlamlı ve pozitif yönlü bir ilişki vardır.

$\mathrm{H}_{4}$ : Sosyal pazarlama faaliyetlerinin algılanan etkinliği ile altruizm arasında anlamlı ve pozitif yönlü bir ilişki vardır.

H5: Sosyal pazarlama faaliyetlerinin algılanan etkinliği ile kan bağışlama niyeti arasında anlamlı ve pozitif yönlü bir ilişki vardır.

Psikoloji literatüründeki kan bağışı ile ilgili çalışmalar gözden geçirildiğinde davranışsal niyetin davranışın güçlü bir belirleyicisi olduğu ortaya konmaktadır (Ferguson, 1996). Bunların yanı, sıra literatür incelendiğinde; kan toplayan kuruluşların karşılaştıkları sorunlardan birisinin gönüllü adaylarının kan bağışı sırasında çeşitli hastalıkların bulaşması ile ilgili korkularıdır. Adam ve Soutar'ın (1999) buna yönelik olarak yaptığ 1 çalışmada algılanan riskin tutumu negatif yönlü etkilediği tespit edilmektedir. Bunun yanı sıra tutumun da kan bağışlama isteği ile arasında pozitif yönlü bir ilişkinin olduğu ifade edilmektedir.

Argan'ın (2016) kan bağışını etkileyen faktörleri planlı davranış bağlamında araştırdığı çalışmada kan bağışına yönelik tutum, öznel norm ve algılanan davranışsal kontrolün kan bağışlama niyeti üzerinde etkisinin olduğu sonucuna ulaşıldığı belirtilmektedir. Kan bağışlama niyeti ile de davranış arasında doğrudan ve pozitif yönlü bir ilişkinin olduğu tespit edilmektedir.

Kan bağışına yönelik PDT çerçevesinde yapılan bir diğer çalışmada, Faqah ve diğerleri (2015) tıp öğrencileri üzerinde yaptıkları uygulamada algılanan davranışsal kontrol ve tutumun kan bağışlama niyetini etkileyen güçlü öncüller olduğu sonucuna varmaktadır. 
Bagot ve diğerlerinin (2015) genişletilmiş PDT çerçevesinde tutum, öznel norm, öz yeterlilik, ahlaki norm, beklenen pişmanlık, kimlik, niyet ve davranış değişkenleri temelinde yaptıkları çalışmada yaptığımız çalışmada da kullandığımız değişkenler olan tutum ve öznel normun niyete, niyetinde davranışa etkisine bakılmaktadır. Yapılan analizler sonucunda tutum ile niyet arasında anlamlı ve pozitif yönlü bir ilişki tespit edilirken, öznel normun niyet üzerinde anlamlı bir etkisi olmadığı sonucuna varılmaktadır. Ayrıca niyetin davranış üzerinde güçlü bir etkisinin olduğu da tespit edilmektedir.

Mirutse ve diğerleri (2014) de kan bağışının niyetini etkileyen önemli belirleyicilerin tutum, kan bağışı konusunda bilgi, öznel norm olduğunu belirtmişlerdir. Bunun yanı sıra çalışmada bireylerin kan bağışına yönelik bilgilerinin arttırılmasının kan bağışı gönüllüsü olunmasına yönelik olumlu tutumları da beraberinde getireceği ifade edilmektedir.

Bednall ve diğerleri (2013) kan bağışına yönelik niyet ve davranışların öncüllerini belirlemeye yönelik yaptıkları meta analiz araştırmasında 61 çalışmanın sonuçlarını incelemektedirler. Araştırmada yapılan analizler sonucunda kan bağışı öncülleri 6 gruba ayrılmaktadır. Bu gruplar; (1) PDT ve (2) uzantıları, (3) duygusal beklentiler, (4) donör deneyimleri, (5) donörlerin geçmişteki davranışları, (6) demografik özellikler olarak ortaya çıkmaktadır.

Holdershaw ve diğerleri (2011) kan bağışlama niyetini belirleme amacıyla mobil Yeni Zelanda Kan Servisi'nde ilk olarak PDT çerçevesindeki değişkenlerle (tutum, öznel norm, algılanan davranışsal kontrol) niyet arasındaki ilişki ele alınmaktadır. Sonrasında ise PDT'nin genişletilmiş versiyonundaki değişkenler de (ahlaki normlar ve geçmiş davranışlar) dahil edilerek ilişkilerin analizi yapılmaktadır. Çalışmada tutum ve algılanan davranışsal kontrol ile niyet arasında anlamlı bir ilişki tespit edildiği ifade edilmektedir.

Merav ve Lena (2010) İsrail vatandaşlarının kan bağışı niyetlerine yönelik yaptıkları çalışmada PDT temelinde tutum, öznel norm ve algılanan davranışsal kontrol ile davranışsal niyet arasındaki ilişkiyi ele almaktadırlar. Buna yönelik olarak 17-60 yaş arasındaki 190 erkek ve kadından elde edilen veriler ile yapılan çalışmada tutum, öznel norm ve algılanan davranışsal kontrol öncüllerinin kan bağışı niyeti arasında anlamlı bir ilişki olduğu ifade edilmektedir. Bunun yanı sıra niyetin gerçekleşen davranış ile paralel olduğu da ortaya konmaktadır.

PDT temelinde konuyla ilgili yapılan bir diğer çalışma da Masser ve diğerleri (2009) tarafından ortaya konmaktadır. Çalışmada PDT faktörleri dışında algılanan pişmanlık, ahlaki norm, korku, kişilik gibi değişkenler de çalışmaya dahil edilmektedir. 182 bağış̧̧ıdan elde edilen sonuçlara göre korku ve tutum arasında negatif ve anlamlı, ahlaki normlar ve kişilik ile tutum arasında pozitif ve anlamlı bir ilişki olduğu ifade edilmektedir. Bunun yanı sıra tutum, öz yetkinlik ve algılanan pişmanlık ile de niyet arasında anlamlı bir ilişki olduğu belirtilmektedir. Ayrıca niyetin de davranış üzerinde büyük bir etkisinin olduğu gözlemlenmektedir.

Kan bağışına yönelik PDT çerçevesinde yapılan çalışmada McMahon ve Byrne (2008) tarafından ortaya konmaktadır. Çalışmada PDT'nin öncüllerine (tutum, öznel norm ve algılanan davranışsal kontrol) ek olarak çeşitli öncüller (geçmiş davranışlar, ahlaki normlar, kişilik ve algılanan pişmanlık) eklenerek yeni bir model oluşturulmaktadır. Kullanılan bu model PDT'nin genişletilmiş versiyonu olarak ifade edilmektedir. Çalışmada kan bağışçılarının ve kan bağış̧̧ısı olmayanların oluşturdukları iki farklı grupla el edilen sonuçlar ortaya konmaktadır. Kan bağışçlarının olduğu gruptan elde edilen sonuçlara göre pişmanlık, tutum, algılanan davranışsal kontrol, kişilik, öznel norm faktörleri kan bağışına yönelik niyete katkıda bulunmaktadır. Kan bağışçısı olmayan gruptan elde edilen verilere göre ise kan bağışı yapmalarının önündeki en büyük engelleri kendilerini zayıf hissetmeleri ve iğne korkusu olarak ifade etmektedirler.

Bu bilgiler doğrultusunda aşağıdaki hipotezler ileri sürülmüştür:

H6: Kan bağışına yönelik tutum ile kan bağışlama niyeti arasında anlamlı ve pozitif yönlü bir ilişki vardır.

H7: Öznel Norm ile kan bağışlama niyeti arasında anlamlı ve pozitif yönlü bir ilişki vardır.

H8: Algılanan Davranışsal Kontrol ile kan bağışlama niyeti arasında anlamlı ve pozitif yönlü bir ilişki vardır.

H9: Altruizm ile kan bağışlama niyeti arasında anlamlı ve pozitif yönlü bir ilişki vardır. 


\subsection{Veri Toplama Yöntemi ve Örneklem Yapısı}

Bu çalışmada Türkiye'de kan bağışı yapabilen kişiler çalışmanın ana kütlesini oluşturmaktadır. Çalışmada, araştırma verilerinin elde edilmesinde kolayda örnekleme yöntemi kullanılmaktadır. Anket formu, araştırmaya katılmaya gönüllü olanlara bilgi verilip onayları alındıktan sonra dağıtılmış ve çalışma kapsamına alınmıştır. Veri toplama uygulaması Ağustos 2017 - Ekim 2017 arasında gerçekleşmiştir. Bu bağlamda araştırma modelinin test edilmesine yönelik olarak 399 adet anket analizlere dahil edilmiştir.

Araştırma ölçeği oluşturulurken 5'li likert ölçeği kullanılmış ve bu bölümde 32 ifadeye yer verilmiştir. Bu kısımda yer alan ifadelerin oluşturulmasında literatürde yer alan bir dizi ölçekten faydalanılmıştır. Bunlardan; tutum (Giles vd., 2004), öznel norm (France vd., 2014), algılanan davranışsal kontrol (France vd., 2014 ve Argan 2016), altruizm (Ferguson vd., 2012), niyet (Giles vd., 2004), sosyal pazarlama faaliyetlerinin algılanan etkinliği (Davis 2011) tarafından geliştirilmiştir.

\section{BULGULAR}

Çalışma dahilinde elde edilen verilerin analizinde, Lisrel 8.80 ve SPSS 20.0 paket programları kullanılmıştır. Çalışmada yer alan analizler, anketi cevaplayanların tanımlayıcı istatistikleriyle ilgili sıklık tabloları, ölçeklerle ilgili olarak faktör analizi, güvenilirlik analizi, değişkenler arasındaki ilişkiyi göstermeye yönelik olarak korelasyon analizi ve araştırma hipotezlerinin test edilebilmesi için yapılan regresyon analizlerinden oluşmaktadır.

Araştırmaya katılanların, 183'ü erkekler ve 216'sı kadınlardan oluşmaktadır. Bunların yüzdelik dağılımları ise, sırasıyla \%45,9 ve $\% 54,1^{\prime}$ dir. Katılımciların $320^{\prime}$ si bekar, $79^{\prime}$ u evli bireylerden oluşmaktadır. Bunların yüzdelik dağılımları ise, sırasıyla \%19,9 ve \%80,2' dir. Katılımcıların yaşları incelendiğinde ise 294 kişinin 1825 yaş aralığında, 77 kişinin 26-35 yaş aralığında, 32 kişinin 36-45 yaş aralığında, 6 kişinin ise 46 yaş ve üstü olduğu görülmektedir. Öte yandan katılımclların büyük çoğunluğunun eğitim düzeylerinin lisans ve üzeri eğitim seviyesinde olduğu görülmektedir.

Tablo 1. Tanımlayıcı İstatistikler

\begin{tabular}{|c|c|c|c|}
\hline Demografik Özellikler & Kategori & Frekans & Yüzde (\%) \\
\hline \multirow{4}{*}{ Cinsiyet } & Kadın & 216 & 54,1 \\
\cline { 2 - 4 } & Erkek & 183 & 45,9 \\
\cline { 2 - 4 } & Toplam & $\mathbf{3 9 9}$ & $\mathbf{1 0 0}$ \\
\hline \multirow{4}{*}{ Yaş } & $18-25$ & 294 & 13,7 \\
\cline { 2 - 4 } & $26-35$ & 77 & 8 \\
\cline { 2 - 4 } & $36-45$ & 32 & 1,5 \\
\cline { 2 - 4 } & 46 ve üzeri & 6 & $\mathbf{1 0 0}$ \\
\cline { 2 - 4 } Medeni Durum & Toplam & $\mathbf{3 9 9}$ & 19,8 \\
\cline { 2 - 4 } & Evli & 79 & 80,2 \\
\cline { 2 - 4 } & Bekar & 320 & $\mathbf{1 0 0}$ \\
\hline \multirow{3}{*}{ Eğitim Düzeyi } & Toplam & $\mathbf{3 9 9}$ & 4,2 \\
\cline { 2 - 4 } & İkögrretim ve Lise & 17 & 10,8 \\
\cline { 2 - 4 } & Önlisans & 43 & 78,2 \\
\cline { 2 - 4 } & Lisans & 312 & 6,8 \\
\cline { 2 - 4 } & Lisansüstü & 27 & $\mathbf{1 0 0}$ \\
\hline
\end{tabular}

Çalışmada kullanılan ölçeklerin geçerliliğini test etmek ve çalışma çerçevesinde kullanılan değişkenleri oluşturan faktörlerin neler olduğu ve bu faktörlerden her birinin değişkenleri açılama derecesini görmek amacıyla keşfedici faktör analizleri (varimax rotasyonu kullanılmıştır) ile modelin bütün olarak geçerliliği test etmek amacıyla da doğrulayıcı faktör analizi yapılmıştır.

Bu bölümde çalışmada kullanılan ölçekler için keşfedici faktör analizleri uygulanmıştır. Burada açıklayıcı faktör analizi yöntemine uygun olarak faktör yükü düşük olan $(<.40)$ çapraz faktör yükü yüksek (>.40) veya özdeğeri düşük olan (<.30) ifadelerin analiz dışında bırakılması söz konusu olmaktadır (Özgül, 2010). Ayrıca faktör analizlerinde temel bileşenler analizi ve Varimax rotasyonu yöntemleri kullanılmaktadır ve öz değerin 
(Eigen value) 1'den büyük olması olarak alınmıştır (Büyüköztürk, 2010: 125). Ölçeklerin keşfedici faktör analizi sonuçları sırasıyla aşağıda gösterilmektedir.

Çalışmada kullanılan ölçeklere yönelik yapılan keşfedici faktör analizleri sonuçları aşağıdaki tablolarda görülmektedir. Altruizm ölçeğindeki "Kendi iyiliğ̈im yerine başkalarının iyiliği için çalışmayı tercih ederim", ifadesinin faktör yükü eşik değer olan $0,4^{\prime}$ ten düşük olduğu tespit edilmiş ve analizden çıkarılmıştır. Öte yandan sosyal pazarlama faaliyetlerinin algılanan etkinliği ölçeği faktör analizi sonucunda beklenildiği gibi tek boyut değil, iki boyutlu bir faktör yapısı ortaya çıkmıştır. Bunun üzerine ifadelerden, "Türk Kızılayı'nın kan bağışına yönelik tanıtımları kafa karıştırıcıdır." ve "Türk Kızılayı'nın kan bağışına yönelik tanıtımlarından hoşlanmam." ifadelerinin diğer ifadelerle anlamsal uyum göstermediği, bu sebeple yeni bir faktör oluşmasına sebep olduğu sonucuna ulaşılmıştır. Bundan dolayı bu iki ifade analiz dışında bırakılarak yeniden faktör analiz yapılmış ve tek boyutlu faktör yapısı elde edilmiştir. Yapılan analizler doğrultusunda bahsi geçen ifadeler dışındaki tüm ifadelerin kabul edilen değer aralığında olduğu tespit edilmiştir.

\section{Tablo 2. Keşfedici Faktör Analizleri}

\begin{tabular}{|c|c|c|}
\hline Tutum & Faktör Yükleri & \\
\hline Kan bağışında bulunmanın iyi bir fikir olduğunu düşünüyorum. & 0,845 & \\
\hline Kan bağışında bulunmanın faydalı olduğunu düşünüyorum. & 0,858 & \\
\hline Kan bağışında bulunmanın değerli bir şey olduğunu düşünüyorum. & 0,904 & \\
\hline Kan bağışında bulunmanın doğru bir şey olduğunu düşünüyorum. & 0,901 & \\
\hline Kan bağışında bulunmanın rahatlatıcı olduğunu düşünüyorum. & 0,689 & \\
\hline Kan bağışında bulunmanın mutluluk verici olduğunu düşünüyorum. & 0,747 & \\
\hline $\begin{array}{l}\text { Toplam Açıklanan Varyans } \\
\text { KMO Örneklem Yeterliliği }\end{array}$ & & $\begin{array}{l}\% 68,529 \\
0,857\end{array}$ \\
\hline Bartlett Küresellik Testi & $\begin{array}{l}\text { Ki-Kare } \\
\text { Df } \\
\text { Sig. }\end{array}$ & $\begin{array}{l}1768,936 \\
15 \\
, 000\end{array}$ \\
\hline Öznel Norm & Faktör Yükleri & \\
\hline $\begin{array}{l}\text { Hayatımdaki önemli insanların birçoğu kan bağışında bulunmamı tavsiye } \\
\text { eder. }\end{array}$ & 0,838 & \\
\hline Ailem kan bağışında bulunmam gerektiğini düşünür. & 0,894 & \\
\hline Hayatımdaki en önemli kişiler kan bağışı yapmam gerektiğini düşünürler. & 0,924 & \\
\hline $\begin{array}{l}\text { Toplam Açıklanan Varyans } \\
\text { KMO Örneklem Yeterliliği }\end{array}$ & & $\begin{array}{l}\% 78,494 \\
0,698\end{array}$ \\
\hline Bartlett Küresellik Testi & $\begin{array}{l}\text { Ki-Kare } \\
\text { Df } \\
\text { Sig. }\end{array}$ & $\begin{array}{l}607,905 \\
3 \\
, 000\end{array}$ \\
\hline Algılanan Davranışsal Kontrol & Faktör Yükleri & \\
\hline Sağlığım kan bağışında bulunabilmek için elverişlidir. & 0,613 & \\
\hline Kan bağışında bulunmak benim için kolaydır. & 0,846 & \\
\hline Sağlığım elverdiği sürece kan bağışında bulunurum. & 0,689 & \\
\hline Kan bağışı için yapılacak müdahalelere dayanabilirim. & 0,871 & \\
\hline Ĕ̆er istersem kan bağışı yapabileceğim konusunda kendime güvenirim. & 0,856 & \\
\hline $\begin{array}{l}\text { Toplam Açıklanan Varyans } \\
\text { KMO Örneklem Yeterliliği }\end{array}$ & & $\begin{array}{l}\% 61,143 \\
0,744\end{array}$ \\
\hline Bartlett Küresellik Testi & $\begin{array}{l}\text { Ki-Kare } \\
\text { Df } \\
\text { Sig. }\end{array}$ & $\begin{array}{l}1010,010 \\
10 \\
, 000\end{array}$ \\
\hline Niyet & Faktör Yükleri & \\
\hline Önümüzdeki 6 ay içinde kan bağışında bulunmayı düşünüyorum. & 0,976 & \\
\hline Önümüzdeki 6 ay içinde büyük olasılıkla kan bağışında bulunacağım. & 0,987 & \\
\hline Önümüzdeki 6 ay içinde kan bağışında bulunacağım. & 0,986 & \\
\hline $\begin{array}{l}\text { Toplam Açıklanan Varyans } \\
\text { KMO Örneklem Yeterliliği }\end{array}$ & & $\begin{array}{l}\% 96,579 \\
0,776\end{array}$ \\
\hline Bartlett Küresellik Testi & $\begin{array}{l}\text { Ki-Kare } \\
\text { Df } \\
\text { Sig. }\end{array}$ & $\begin{array}{l}1987,548 \\
3 \\
, 000\end{array}$ \\
\hline
\end{tabular}




\begin{tabular}{|c|c|c|}
\hline Altruizm & Faktör Yükleri & \\
\hline Toplumun iyiliği için çalışmalar yapmaya çabalarım. & 0,767 & \\
\hline Başkalarına yardım etmekle çok ilgili değilim. & 0,724 & \\
\hline Başkalarına yardım etmek benim için önemlidir. & 0,848 & \\
\hline İhtiyaç sahiplerine yardım etmenin önemli olduğunu düşünürüm. & 0,734 & \\
\hline Toplam Açıklanan Varyans & & $\% 59,237$ \\
\hline KMO Örneklem Yeterliliği & & 0,755 \\
\hline \multirow{3}{*}{ Bartlett Küresellik Testi } & Ki-Kare & 410,378 \\
\hline & Df & 6 \\
\hline & Sig. & , 000 \\
\hline Sosyal Pazarlama Faaliyetlerinin Algılanan Etkinliği & Faktör Yükleri & \\
\hline Türk Kızılayı'nın kan bağışına yönelik tanıtımları ilgimi çeker. & 0,786 & \\
\hline Türk Kızılayı'nın kan bağışına yönelik tanıtımları ikna edicidir. & 0,786 & \\
\hline $\begin{array}{l}\text { Türk Kızılayı'nın kan bağışına yönelik tanıtımları bana önemli bir mesaj } \\
\text { verir. }\end{array}$ & 0,838 & \\
\hline $\begin{array}{l}\text { Türk Kızılayı'nın kan bağışına yönelik tanıtımları kan bağışlamam için iyi } \\
\text { bir neden verir. }\end{array}$ & 0,826 & \\
\hline Türk Kızılayı'nın kan bağışına yönelik tanıtımları bana hitap eder. & 0,809 & \\
\hline $\begin{array}{l}\text { Türk Kızılayı'nın kan bağışına yönelik tanıtımları nasıl kan bağı̧̧ı } \\
\text { yapabileceğim konusunda beni bilgilendirir. }\end{array}$ & 0,673 & \\
\hline $\begin{array}{l}\text { Türk Kızılayı'nın kan bağışına yönelik tanıtımlarından yeni bir şeyler } \\
\text { öğrenirim. }\end{array}$ & 0,780 & \\
\hline Türk Kızılayı'nın kan bağışına yönelik tanıtımlarını genel olarak severim. & 0,856 & \\
\hline Toplam Açıklanan Varyans & & $\% 63,360$ \\
\hline KMO Örneklem Yeterliliği & & 0,901 \\
\hline \multirow[t]{3}{*}{ Bartlett Küresellik Testi } & Ki-Kare & 2100,169 \\
\hline & Df & 28 \\
\hline & Sig. & , 000 \\
\hline
\end{tabular}

Sosyal bilimler çerçevesinde yapılan çalışmalarda keşfedici faktör analizi sonrasında doğrulayıcı faktör analizi uygulanan bir yöntem olmaktadır. Yöntemin keşfedici analizden daha katı bir istatistiksel test sürecine sahip olması nedeniyle analiz sonrası elde edilen yapının daha sağlıklı ve hatasız yönteme sahip olduğu ifade belirtilmektedir (Özgül, 2010; Şimşek, 2007).

Araştırmada kullanılan ölçeklerin geçerliliğini test etmek amacıyla doğrulayıcı faktör analizi (DFA) yapılmıştır. DFA, gizil değişken analizi olarak bilinmekte ve kuramsal bir temeli olan nedensel modellerin sınanmasında kullanılmaktadır (Sümer, 2000: 49). Modellerin analizinde genellikle Ki-Kare Uyum testi $\left(\Delta \chi^{2}\right)$, $\Delta \chi^{2 \prime}$ nin serbestlik derecesine bölünmesiyle ortaya çıkan $\Delta \chi 2 / \mathrm{df}$, karşılaştırmalı uyum indeksi (comparative fit index, CFI), iyilik uyum indeksi (GFI), fazlalık uyum indeksi (incremental fit index, IFI), yaklaşık hataların ortalama karekökü (root mean square error of approximation, RMSEA) değerleri kullanılmaktadır. Model uyumunun iyi olduğuna bu değerlerden $\Delta \chi 2 /$ df değerinin 5 'ten küçük olması, $\Delta \chi^{2}$ nin anlamlı olmaması, GFI, CFI ve IFI değerlerinin ise $0,90^{\prime}$ dan büyük olması, RMSEA değerinin $0,08^{\prime}$ den küçük olması doğrultusunda karar verilmektedir (Şimşek, 2007).

Çalışma dahilinde 6 değişkenin ölçeği için daha önce yapılan keşfedici faktör analizlerinde ortaya çıkmış olan boyutlar ile doğrulayıcı faktör analizi yapılmıştır. Elde edilen analiz sonucuna göre ortaya çıkan uyum değerlerinin yeterince yüksek olmaması nedeniyle, faktör yüklerinin problemli olduğu görülen bazı ifadeler analiz dışında bırakılmıştır. Bu ifadeler algılanan davranışsal kontrol değişkenine ait "Sağ̆lı̆̆ım kan bă̆ışında bulunabilmek için elverişlidir.", ifadesi ile sosyal pazarlama faaliyetlerinin algılanan etkinliği değişkeninde yer alan "Türk Kızılayı'nın kan bağışına yönelik tanıtımları ilgimi çeker." ve "Türk Kızılayı'nın kan bağışına yönelik tanıtımları ikna edicidir." ifadeleridir. Bu ifadeler analiz dışında bırakıldıktan sonra elde edilen 6 değişkenli yapı yeniden analiz edilmiş ve kabul edilebilir uyum değerlerine ulaşılmıştır. Modelin 6 değişkenli yapısına ait uyum değerleri Tablo 3'te gösterilmiştir. Ayrıca Şekil 2'de ölçeklerin doğrulayıcı faktör analizi sonucunda ortaya çıkan faktör yükleri gösterilmiştir. Analiz sonuçlarına göre, uyum değerlerinin olması gereken değerlerin üzerinde olduğu görülmektedir. Tablo 3'te de görüldüğü üzere, GFI, CFI ve IFI değerlerinin sirasıyla $0,90,0,98$ ve 0,98 olduğu ve kabul edilebilir değer olan $0,9^{\prime}$ un üzerinde olduğu; RMSEA değerinin 0,045 olduğu ve 0,08 değerinin altında olduğu gözlenmektedir. 
Tablo 3. Araştırma Modelinin Doğrulayıcı Faktör Analizi

\begin{tabular}{|c|c|c|c|c|c|c|}
\hline $\mathbf{\Delta} \chi \mathbf{2}$ & $\mathbf{d f}$ & $\boldsymbol{\Delta} \mathbf{\chi} \mathbf{2} / \mathbf{d f}$ & $\mathbf{R M S E A}$ & GFI & CFI & IFI \\
\hline 510,26 & 277 & 1,842 & 0,046 & 0,91 & 0,98 & 0,98 \\
\hline
\end{tabular}

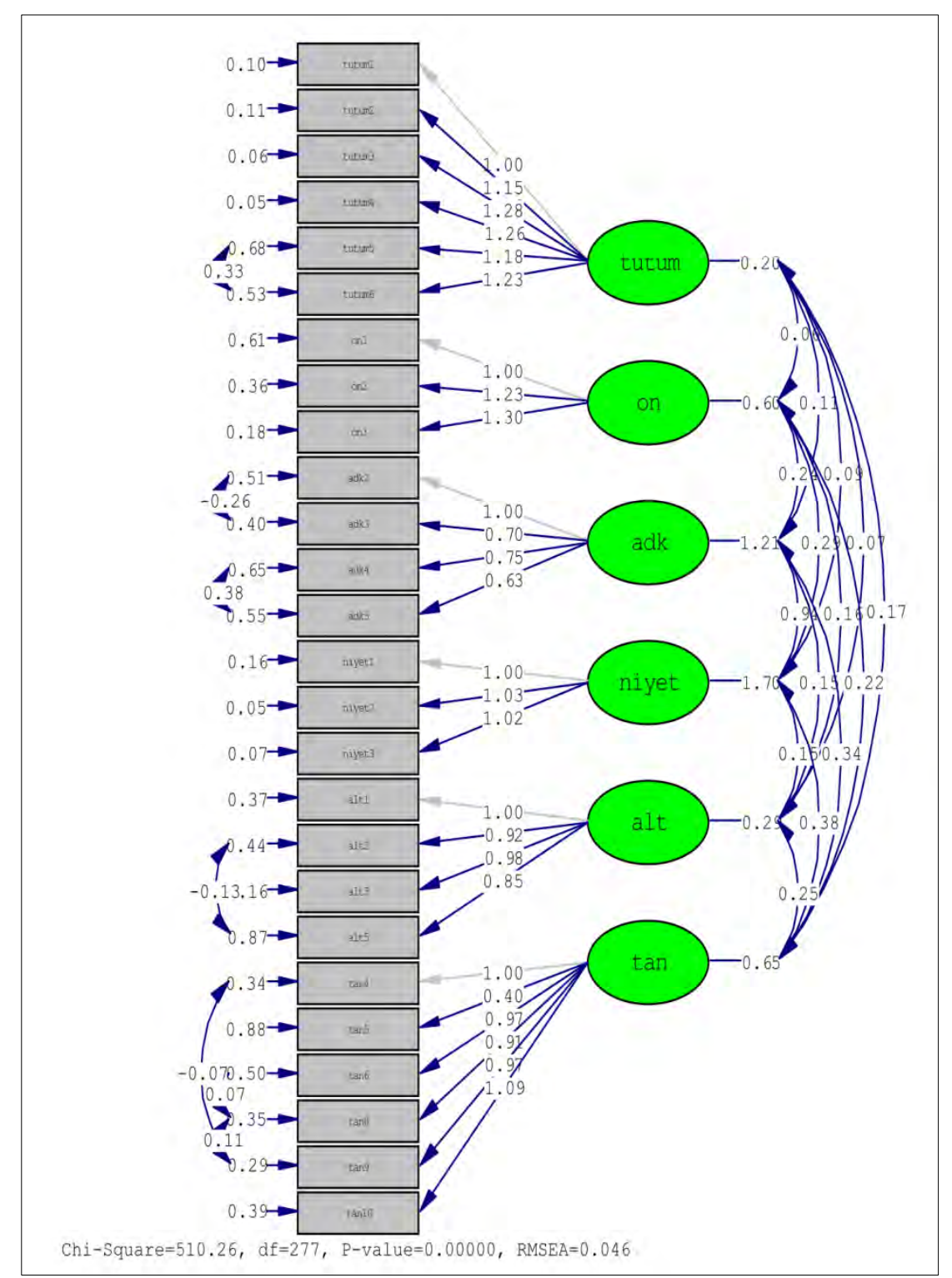

Şekil 2. Araştırma Modelinin Doğrulayıcı Faktör Analizi

Araştırma çerçevesinde güvenilirlik ölçümü için literatürdeki diğer çalışmalarda da genelde kullanılan Cronbach Alpha ( $\alpha$ ) değeri kullanılmaktadır (Özdamar, 1999: 513). Güvenilirlik analizinde, faktör analizinde elde edilen sonuçlar çerçevesindeki ölçeklerde yapılan değişikliklere de dikkat edilerek, her değişkenin alfa katsayıları incelenmiştir. Bu doğrultuda, Tablo 4'te çalışmadaki değişkenleri ve bunların Cronbach Alpha $(\alpha)$ katsayıları görülebilmektedir. Cronbach Alpha $(\alpha)$ katsayılarının 0,758 ile 0,982 arasında değiştiği ve kabul edilebilir düzeyde olduğu görülmektedir.

Tablo 4. Ölçeklere Ait Güvenilirlik Katsayıları

\begin{tabular}{|l|l|l|}
\hline Değişkenler & Soru sayısı & Alfa Katsayı1sı $(\boldsymbol{\alpha})$ \\
\hline Tutum & 6 & 0,883 \\
\hline Öznel Norm & 3 & 0,862 \\
\hline Algılanan Davranışsal Kontrol & 4 & 0,845 \\
\hline Altruizm & 4 & 0,758 \\
\hline Niyet & 3 & 0,982 \\
\hline Sosyal Paz. Faal. Algılanan Etkinliği & 6 & 0,894 \\
\hline
\end{tabular}


Korelasyon analizinde değişkenlere yönelik Pearson Korelasyon katsayıları, ortalama, korelasyon değerleri ve standart sapma hesaplanmıştır. Çalışma dahilindeki değişkenlerin birbirleri ile arasındaki korelasyonlara bakıldığında, değerlerin 0,183 ile 0,592 arasında değiştiği görülmektedir.

Tablo 5. Değişkenlere Ait Tanımlayıcı İstatistikler ve Değişkenler Arası Korelasyon Katsayıları

\begin{tabular}{|l|l|l|l|l|l|l|l|l|l|}
\hline Değiskenler & Ort. & SS & $\mathbf{1}$ & $\mathbf{2}$ & $\mathbf{3}$ & $\mathbf{4}$ & $\mathbf{5}$ & $\mathbf{6}$ \\
\hline 1 & Tutum & 4,59 & 0,57 & 1 & & & & & \\
\hline 2 & Öznel Norm & 3,59 & 0,98 & $0,224^{* *}$ & 1 & & & & \\
\hline 3 & $\begin{array}{l}\text { Alg1lanan } \\
\text { Dav. Kont. }\end{array}$ & 4,05 & 0,93 & $0,253^{* *}$ & $0,218^{* *}$ & 1 & & & \\
\hline 4 & Altruizm & 4,14 & 0,55 & $0,292^{* *}$ & $0,301^{* *}$ & $0,226^{* *}$ & 1 & & \\
\hline 5 & Tutundurma & 3,88 & 0,82 & $0,457^{* *}$ & $0,335^{* *}$ & $0,295^{* *}$ & $0,424^{* *}$ & 1 & \\
\hline 6 & Niyet & 3,35 & 1,33 & $0,209^{* *}$ & $0,258^{* *}$ & $0,592^{* *}$ & $0,183^{* *}$ & $0,312^{* *}$ & 1 \\
\hline${ }^{*} 0,05$ seviyesinde anlaml & * 0,01 seviyesinde anlaml \\
\hline
\end{tabular}

Çalışma çerçevesinde ortya konan hipotezleri test etmek için regresyon analizleri yapılmıştır ve analizler sonucunda elde edilen sonuçlar aşağıda açıklanmıştır. Sosyal pazarlama faaliyetlerinin algılanan etkinliği ile tutum arasındaki ilişkiyi incelemek için ortaya konulan regresyon modeline yönelik uygulanan analiz sonucunda, modelin istatistiki açıdan anlamlı olduğu bulgulanmaktadır $(F=93,883 ; p<0,01)$. Sosyal pazarlama faaliyeti etkinliği ile tutum arasındaki regresyon analizinde görüldüğü üzere $R^{2}$ değeri 0,189 'dur. Buna göre sosyal pazarlama faaliyetlerinin algılanan etkinliği tutumun yaklaşık \%19'unu açılamaktadır. Analiz sonuçlarına göre, Sosyal pazarlama faaliyeti etkinliği ile tutum $(\beta=0,437, \mathrm{p}<0.01)$ arasında pozitif yönlü ve anlamlı bir ilişki olduğu görülmüştür. Bundan dolayı $\mathrm{H}_{1}$ hipotezi desteklenmektedir. Bu modele yönelik veriler Tablo 6'da gösterilmiştir.

Tablo 6. Sosyal Pazarlama Faaliyetlerinin Algılanan Etkinliğinin Tutum Üzerindeki Etkisine Yönelik Regresyon Analizi

\begin{tabular}{|l|l|l|l|}
\hline Bağımsız değişkenler & S. Beta & $\mathbf{t}$ & $\mathbf{p}$ \\
\hline Sosyal Pazarlama Faaliyetlerinin Algılanan Etkinliği & 0,437 & 9,689 & 0,000 \\
\hline $\mathrm{F}=93,883 \quad$ Düz. $\mathrm{R}^{2}=0,189 \quad \mathrm{p}=0,000$ & \multicolumn{2}{l}{} \\
\hline
\end{tabular}

Bağımlı Değişken: Tutum

Sosyal pazarlama faaliyeti etkinliği ile öznel norm arasındaki ilişkiyi incelemek için ortaya konulan regresyon modeline yönelik uygulanan analiz sonucunda, modelin istatistiki açıdan anlamlı olduğu bulgulanmaktadır $(\mathrm{F}=50,279 ; \mathrm{p}<0,01)$. Sosyal pazarlama faaliyeti etkinliği ile öznel norm arasındaki regresyon analizinde görüldüğü üzere $R^{2}$ değeri 0,110 'dur. Buna göre sosyal pazarlama faaliyetlerinin algılanan etkinliği öznel normun yaklaşık \%11'ini açılamaktadır. Analiz sonuçlarına göre, sosyal pazarlama faaliyeti etkinliği ile öznel norm $(\beta=0,335, p<0.01)$ arasında pozitif yönlü ve anlamlı bir ilişki olduğu görülmüştür. Bundan dolayı $\mathrm{H}_{2}$ hipotezi desteklenmektedir. Bu modele yönelik veriler Tablo 7'de gösterilmiştir.

Tablo 7. Sosyal Pazarlama Faaliyetlerinin Algılanan Etkinliğinin Öznel Norm Üzerindeki Etkisine Yönelik Regresyon Analizi

\begin{tabular}{|l|l|l|l|}
\hline Bağımsız değişkenler & S. Beta & t & p \\
\hline Sosyal Pazarlama Faaliyetlerinin Algılanan Etkinliği & 0,335 & 7,091 & 0,000 \\
\hline$F=50,279 \quad$ Düz. $\mathrm{R}^{2}=0,110 \quad \mathrm{p}=0,000$ & \\
\hline
\end{tabular}

Bağımlı Değişken: Öznel Norm

Sosyal pazarlama faaliyeti etkinliği ile algılanan davranışsal kontrol arasındaki ilişkiyi incelemek için ortaya konulan regresyon modeline yönelik uygulanan analiz sonucunda, modelin istatistiki açıdan anlamlı olduğu bulgulanmaktadır $(\mathrm{F}=37,896 ; \mathrm{p}<0,01)$. Sosyal pazarlama faaliyeti etkinliği ile algılanan davranışsal kontrol arasındaki regresyon analizinde görüldüğü üzere $\mathrm{R}^{2}$ değeri $0,085^{\prime}$ tir. Buna göre sosyal pazarlama faaliyetlerinin algılanan etkinliği algılanan davranışsal kontrolün yaklaşık \%8'sini açıklamaktadır. Analiz sonuçlarına göre, sosyal pazarlama faaliyeti etkinliği ile algılanan davranışsal kontrol $(\beta=0,295, p<0.01)$ arasında pozitif yönlü ve anlamlı bir ilişki olduğu görülmüştür. Bundan dolayı $\mathrm{H}_{3}$ hipotezi desteklenmektedir. Bu modele yönelik veriler Tablo 8'de gösterilmiştir. 
Tablo 8. Sosyal Pazarlama Faaliyetlerinin Algılanan Etkinliğinin Algılanan Davranışsal Kontrol Üzerindeki Etkisine Yönelik Regresyon Analizi

\begin{tabular}{|l|l|l|l|}
\hline Bağımsız değişkenler & S. Beta & $\mathbf{t}$ & $\mathbf{p}$ \\
\hline Sosyal Pazarlama Faaliyetlerinin Algılanan Etkinliği & 0,295 & 6,156 & 0,000 \\
\hline $\mathrm{F}=37,896$ Düz. $\mathrm{R}^{2}=0,085 \quad \mathrm{p}=0,000$
\end{tabular}

Bağımlı Değişken: Algılanan Davranışsal Kontrol

Sosyal pazarlama faaliyeti etkinliği ile altruizm arasındaki ilişkiyi incelemek için ortaya konulan regresyon modeline yönelik uygulanan analiz sonucunda, modelin istatistiki açıdan anlamlı olduğu bulgulanmaktadır $(\mathrm{F}=87,233 ; \mathrm{p}<0,01)$. Sosyal pazarlama faaliyeti etkinliği ile altruizm arasındaki regresyon analizinde görüldüğü üzere $R^{2}$ değeri 0,178 'dir. Buna göre sosyal pazarlama faaliyetlerinin algılanan etkinliği altruizmin yaklaşık $\% 18^{\prime}$ sini açıklamaktadır. Analiz sonuçlarına göre, sosyal pazarlama faaliyeti etkinliği ile altruizm $(\beta=0,424$, $\mathrm{p}<0.01)$ arasında pozitif yönlü ve anlamlı bir ilişki olduğu görülmüştür. Bundan dolayı $\mathrm{H}_{4}$ hipotezi desteklenmektedir. Bu modele yönelik veriler Tablo 9'da gösterilmiştir.

Tablo 9. Sosyal Pazarlama Faaliyetlerinin Algılanan Etkinliğinin Altruizm Üzerindeki Etkisine Yönelik Regresyon Analizi

\begin{tabular}{|l|l|l|l|}
\hline Bağımsız değişkenler & S. Beta & $\mathbf{t}$ & $\mathbf{p}$ \\
\hline Sosyal Pazarlama Faaliyetlerinin Algılanan Etkinliği & 0,424 & 9,340 & 0,000 \\
\hline $\mathrm{F}=87,233 \quad$ Düz. $\mathrm{R}^{2}=0,178 \quad \mathrm{p}=0,000$ & \multicolumn{2}{l|}{} \\
\hline
\end{tabular}

Bağımlı Değişken: Altruizm

Sosyal pazarlama faaliyeti etkinliği ile kan bağışlama niyeti arasındaki ilişkiyi incelemek için ortaya konulan regresyon modeline yönelik uygulanan analiz sonucunda, modelin istatistiki açıdan anlamlı olduğu bulgulanmaktadır ( $\mathrm{F}=42,857 ; \mathrm{p}<0,01)$. Sosyal pazarlama faaliyeti etkinliği ile kan bağışlama niyeti arasındaki regresyon analizinde görüldüğü üzere $\mathrm{R}^{2}$ değeri 0,095'tir. Buna göre sosyal pazarlama faaliyetlerinin algılanan etkinliği kan bağışlama niyetinin yaklaşık \%9'unu açıklamaktadır. Analiz sonuçlarına göre, sosyal pazarlama faaliyeti etkinliği ile kan bağışlama niyeti $(\beta=0,312, p<0.01)$ arasında pozitif yönlü ve anlamlı bir ilişki olduğu görülmüştür. Bundan dolayı $\mathrm{H}_{5}$ hipotezi desteklenmektedir. $\mathrm{Bu}$ modele yönelik veriler Tablo $10^{\prime}$ da gösterilmiştir.

Tablo 10. Sosyal Pazarlama Faaliyetlerinin Algılanan Etkinliğinin Kan Bağışlama Niyeti Üzerindeki Etkisine Yönelik Regresyon Analizi

\begin{tabular}{|l|l|l|l|}
\hline Bağımsız değişkenler & S. Beta & $\mathbf{t}$ & $\mathbf{p}$ \\
\hline Sosyal Pazarlama Faaliyetlerinin Algılanan Etkinliği & 0,312 & 6,547 & 0,000 \\
\hline $\mathrm{F}=42,857 \quad$ Düz. $\mathrm{R}^{2}=0,095 \quad \mathrm{p}=0,000$ & \multicolumn{4}{l|}{} \\
\hline
\end{tabular}

Bağımlı Değişken: Kan Bağışlama Niyeti

Tutum, algılanan davranışsal kontrol, öznel norm ve altruizm ile kan bağışlama niyeti arasındaki ilişkiyi incelemek için ortaya konulan regresyon modeline yönelik uygulanan analiz sonucunda, modelin istatistiki açıdan anlamlı olduğu bulgulanmaktadır $\left(F=115,463 ; R^{2}=0,365 ; p=0,01\right)$. Ancak bağımsız değişkenlerin modeli anlamlı şekilde açıladığını ifade eden $t$ katsayıları anlamsız olarak çıkan tutum ve altruizm modelden çıkartılmıştır. Bu çerçevede öznel norm ve algılanan davranışsal kontrol ile kan bağışlama niyeti arasındaki regresyon analizinde görüldüğ̈̈ üzere $R^{2}$ değeri $0,363^{\prime}$ tür. Buna göre öznel norm ve algılanan davranışsal kontrol kan bağışlama niyetinin yaklaşık \%36'sını açıklamaktadır. Analiz sonuçlarına göre öznel norm ve algilanan davranışsal kontrol (sırasıyla $\beta=0,135, p<0,05 ; \beta=0,563, p<0,01$ ) ile kan bağışlama niyeti arasında pozitif yönlü ve anlamlı bir ilişki olduğu görülmüştür. Bundan dolayı $\mathrm{H}_{7}$ ve $\mathrm{H}_{8}$ hipotezleri desteklenmektedir. Bunların yanı sıra tutum ve altruizm ile kan bağışlama niyeti arasında anlamlı bir ilişki tespit edilememiştir. Dolayısıyla $\mathrm{H}_{6}$ ve $\mathrm{H}_{9}$ hipotezleri reddedilmektedir. Bu modele yönelik veriler Tablo 11'de gösterilmiştir.

Tablo 11. Tutum, Öznel Norm, Algılanan Davranışsal Kontrol ve Altruizmin Kan Bağışlama Niyeti Üzerindeki Etkisine Yönelik Regresyon Analizi

\begin{tabular}{|l|c|c|c|}
\hline Bağimsız değişkenler & S. Beta & t & p \\
\hline Öznel Norm & 0,135 & 3,294 & 0,001 \\
\hline Algilanan Dav. Kont. & 0,563 & 13,757 & 0,000 \\
\hline F=115,463 Düz. $R^{2}=0,365 \quad p=0,001$ & \multicolumn{5}{l}{} \\
\hline
\end{tabular}

Bağımlı Değişken: Kan Bağışlama Niyeti 


\section{SONUÇ VE TARTIŞMA}

Yapılan bu çalışmada, temel olarak; bireylerin gönüllülük niyetini etkileyen değişkenler ile gönüllülük niyeti arasındaki ilişkiler ve sosyal pazarlama faaliyetlerinin algılanan etkinliğinin bu değişkenler üzerindeki etkisi belirlenmeye çalışılmıştır. Bu çerçevede öncelikle, sosyal pazarlama faaliyetlerinin algılanan etkinliğinin tutum, öznel norm, algılanan davranışsal kontrol, altruizm ve gönüllülük niyeti üzerindeki etkilerinin ortaya çıkarılması amaçlanmıştır. Ayrıca, sosyal pazarlama faaliyetlerinin algılanan etkinliği ile tutum, öznel norm, algılanan davranışsal kontrol, altruizm ve gönüllülük niyeti arasındaki ilişkiler dışında; tutum, öznel norm, algılanan davranışsal kontrol ve altruizm ile gönüllülük niyeti arasındaki ilişkiler de incelenmiştir.

Araştırma çerçevesinde ileri sürülen hipotezleri test etmek üzere yapılan analizler sonucunda sosyal pazarlama faaliyetlerinin algılanan etkinliğinin; tutum, öznel norm, algılanan davranışsal kontrol ve altruizm üzerinde pozitif bir etkisinin olduğu görülmektedir. Öte yandan sosyal pazarlama faaliyetlerinin algılanan etkinliği ile gönüllülük niyeti arasında da pozitif ve anlamlı bir ilişki olduğu tespit edilmektedir. Elde edilen bu çıktılar; literatürde incelenen çalışmalarda sosyal pazarlama faaliyetlerinin amacına yönelik elde edilmeye çalışılan çıktılar ile örtüşmektedir (Alvaro vd., 2013; Davis vd., 2016; Davis vd., 2011; Dillard vd., 2007; Marchand, 2010; Schuster vd., 2016). Bu bağlamda sosyal pazarlama faaliyetlerinin algılanan etkinliğinin niyeti belirli bir ölçüde etkilediğini ifade etmek mümkündür. Bu da kan bağışı konusunda yapılan tanıtım faaliyetlerinin bireyleri kan bağışına yönlendirdiğini ortaya koymaktadır.

Öznel norm ile algılanan davranışsal kontrol ile kan bağışlama niyeti arasında ise literatürdeki çalışmalarla (Ferguson, 1996; Armitage ve Conner, 2001; Masser vd., 2009; Merav ve Lena, 2010; Holdershaw vd., 2011; Bagot vd., 2015; Argan, 2016) örtüşen sonuçlar elde edilmiştir. Literatürdeki pek çok çalışmaya paralel olarak öznel norm ve algılanan davranışsal kontrol ile kan bağışlama niyeti arasında anlamlı ilişki tespit edildiği belirlenmektedir.

Kan bağışına yönelik tutum ve altruizm ile kan bağışlama niyeti arasında ise anlamlı bir ilişki olmadığı tespit edilmektedir. Elde edilen bu sonuç literatürdeki benzer çalışmalardaki (Fernandez Montoya vd., 1998; Adam ve Soutar, 1999; Glynn, 2002; Garcia Gutierrez vd., 2003; Misje vd., 2005; Zaller vd., 2005; Javadzadeh Shahshahani vd., 2006; Holdershaw vd., 2011; Mirutse vd., 2014; Merav ve Lena, 2010) sonuçların aksini yansıtmaktadır. Bu sonucun ortaya çıkmasındaki sebep olarak çalışılan konunun kan bağışı özelinde olmasından kaynaklandığı düşünülmektedir. Bireylerin kan bağışına yönelik tutum ve niyetleri arasındaki bağın bir ürünü alma sürecindeki gibi olmaması; kan bağışına yönelik tutum ile kan bağışlama niyeti arasındaki ilişkinin kurulamamasının nedeni olarak görülmektedir. Öte yandan yapılan pek çok çalışmada altruizm kan bağışında bulunmanın başlıca nedenlerinden biri olarak görülse de (Fernandez Montoya vd., 1998; Glynn, 2002; Garcia Gutierrez vd., 2003; Misje vd., 2005; Zaller vd., 2005; Javadzadeh Shahshahani vd., 2006), bu çalışmada altruizm ile kan bağışlama niyeti arasında anlamlı bir ilişki tespit edilememiştir. Literatürdeki sonuçlarla örtüşmeyen bu durumun; altruizmin genel olarak, kişilerin aile bireylerinden birinin zor duruma düşmesinde ortaya çıkan bir kavram olmasından kaynaklandığı düşünülmektedir. Ayrıca bireylerin kan bağışlamasının önünde; kan alma süreci korkusu, fiziksel risk (hastalık bulaşması), psikolojik (korku), sosyal (ahlaki sorumluluk) ve zaman (zaman kaybı) gibi birçok engel olduğu (Andaleeb ve Basu, 1995; Nonis vd., 1996; Ownby vd., 1999; Zaller vd., 2005; Javadzadeh Shahshahani vd., 2006; McMahon vd., 2008) ve bu engellerden ötürü bu tutum ve altruizm ile kan bağışlama arasında anlamlı bir ilişki olmadığı düşünülmektedir.

Bunların yanı sıra Giles ve Cairn (1995), Armitage ve Conner (2001), Giles ve diğerleri de (2003), Masser ve diğerleri (2009), Holdershaw ve diğerleri (2011) yapmış oldukları çalışmalarda PDT'nin kan bağışlama niyetini ve davranışını doğru bir şekilde tahmin eden model olduğunu ifade etmişlerdir. Litetürde incelenen çalışmalar doğrultusunda PDT'nin kan bağışlama davranışını davranışını iyi bir şekilde tahmin ettiğini söylemek mümkün olmaktadır. Yapılan bu çalışmada da öznel norm ve algılanan davranışsal kontrolün kan bağışlama niyetinin \%36'sını açıkladığı belirlenmiştir.

Sosyal pazarlamanın; belli fikirleri, tutumları, davranışları değiştirmeye yönelik organize bir çaba olarak görüldüğ̈̈ (Andreasen, 1994) göz önüne alındığında, sosyal pazarlama faaliyetlerinin algılanan etkinliği ile gönüllülük niyeti arasında anlamlı bir ilişkinin tespit edilmesinin önemli bir bulgu olduğu düşünülmektedir. Kan bağışı gibi toplumsal açıdan son derece önemli ve süreklilik arz eden bir konudaki faaliyetlerin bireylere etki etmesi son derece önemli olmaktadır. Kan bağışı konusunda yapılan faaliyetler, kan bağışına ihtiyacı olan 
bireyleri ve kan bağışı konusunda gönüllü bireyleri ortak noktada buluşturarak köprü görevi görmektedir. Dolayısıyla yapılan faaliyetlerin toplumsal bir fayda sağladığı görülmektedir. Bu açıdan bakıldığında; kan bağışıyla ilgili faaliyetlerin arttırılması, sosyal pazarlama faaliyetleri çerçevesinde doğru hedef kitleye doğru mesajların ulaştırılması ve buna bağlı olarak bağışların arttırılmasının faaliyetler sonucunda elde edilen bu toplumsal faydayı arttıracağı düşünülmektedir.

Yapılan çalışma; ortaya koyduğu teorik ve uygulamaya ilişkin sonuçlarla beraber kısıtlamalara da sahiptir. Öncelikle, bu çalışma Çanakkale ilinde uygulanmıştır. Aynı çalışmanın farklı şehirlerde ve ülkelerde uygulanması durumunda farklı sonuçlar ortaya çıkabileceği düşünülmektedir. Bunun yanı sıra çalışmada oluşturulan model PDT çerçevesindeki değişkenler olan: Tutum, öznel norm, algılanan davranışsal kontrol, niyet ve modele literatürdeki çalışmalardan yararlanılarak eklenen altruizm aracılığıyla ortaya konmuştur. Elde edilen sonuçların genelleştirilebilmesini sağlamak için farklı değişkenler ile sosyal pazarlama ve gönüllülük davranışlarını konu alan çok sayıda ve farklı ülkelerde araştırma yapılmasına ihtiyaç vardır. Çalışmayla ilgili bir diğer kısıt ise sosyal pazarlama faaliyetlerinin algılanan etkinliğinin sadece tutundurma faaliyetleri boyutuyla ele alınmasıdır. Gelecekteki araştırmalarda pazarlamanın diğer fonksiyonları da ele alınarak çalışmalar ortaya konabilir. Bunun yanı sıra çalışmada gönüllülük davranışı PDT temelinde ele alınmaktadır. Bireylerin davranışlarını etkileyen birçok değişken olduğu göz önüne alınırsa farklı teoriler temelinde çalışmaların yapılmasının faydalı olacağı düşünülmektedir. Ayrıca yapılan çalışmada katılımcılara kan bağışı odaklı sorular sorulmaktadır. Gelecekte yapılacak araştırmalarda organ bağışı, çevrecilik, obezite, kalp hastalıkları gibi diğer toplumsal konular araştırılabilir.

Pazarlama faaliyetlerinin sadece kâr amacı ile değil bunun yanı sıra sosyal fayda sağlama amacıyla da uygulanabileceği konular da bulunmaktadır. Bunlara sağlık, eğitim, çevrecilik gibi konular örnek gösterilebilir. Sosyal pazarlama faaliyetlerinde de aynı ticari pazarlama faaliyetlerinde olduğu gibi uygulayıcıların izlemesi gereken adımlar bulunmaktadır. Sosyal pazarlama faaliyetleri uygulamacılarının izlemesi gereken adımlar; pazar araştırması, hedef kitle belirleme, bölümlendirme, bütçe ve plan oluşturma aşamaları olarak ifade edilebilmektedir. Sosyal pazarlama faaliyetlerinin istenilen sonuçlara ulaşması, yani toplumsal refahı arttırma yönünde davranış değişikliği yaratması için; çalışmada daha önce de bahsedildiği gibi istenilen hedef kitleye mesajların doğru şekilde ulaştırılması ile mümkündür. Burada uygulayıcılara düşen görev hedef kitleyi olabilecek en doğru şekilde belirleyip istenilen mesajı en geniş çerçevede bu hedef kitleye ulaştırmaktır. Aksi takdirde ortaya konan faaliyetlerin verimsiz olması dahası ortaya konan çabaların boşa gitmesi gibi durumlar ortaya çıkabilecektir.

Bu çalışmanın gelecekte yapılan akademik çalışmalar ve bunun yanı sıra yürütülecek kan bağışı faaliyetlerine çeşitli yönlerden katkı sağlayacağı düşünülmektedir. Öncelikle yapılan bu çalışma kan bağışı gibi halk sağlığı açısından büyük önem taşıyan bir konuyu yürütülen faaliyetlerin sonuçları açısından ele almaktadır. Elde edilen bu sonuçların örgütlerin gelecekteki faaliyetlerini yönlendirebilmesi muhtemeldir. Sonuç olarak düzenlenen faaliyetlerin bireyleri etkilediği görülmekte ve bu sonucun kan bağışı faaliyetleri yürüten örgütler için önemli olduğu düşünülmektedir. Diğer açıdan bu çalışma kan bağışı konusunda yürütülen faaliyetlerin etkinliğinin kan bağışı niyetini etkileme konusunda niceliksel bir sonuç sunmaktadır. Bu çalışmadaki yöntem ve sonuçların gelecekteki faaliyetler için ön bilgi olma konusunda yararlı olacağı düşünülmektedir. Bunun yanı sıra çalışmadaki analizlerden elde edilen sonuçların gelecekteki kan bağışı konusundaki tanıtım faaliyetlerinin planlanması konusunda da katkı sağlayacağı düşünülmektedir.

\section{KAYNAKÇA}

Adam, Douglas; Soutar, Geoffrey N. (1999). A proposed model of the blood donation process. Conference Proceedings: Australian and New Zealand Marketing Academy Conference, (Sydney).

Ajzen, Icek (2008). Consumer attitudes and behavior, In C.P. Haugtvedt, P.M. Herr \& F.R. Cardes (Eds.), Handbook of consumer psychology (525-548), 2008, New York: Lawrence Erlbaum Associates.

Ajzen, Icek (1991). The Theory of Planned Behavior. Organizational Behavior and Human Decision Processes, 50, 179-211.

Alessandrini, Megan (2007). Community Volunteerism and Blood Donation: Altruism as a Lifestyle Choice. Transfusion Medicine Reviews, 21(4), 307-316. 
Alvaro, E. M.; Crano, W.D.; Siegel, J.T.; Hohman, Z.; Johnson, I.; Nawaki, B. (2013). Adolescents' attitudes toward antimarijuana ads, usage intentions, and actual marijuana usage. Psychology of Addictive Behaviors, 27, 1027-1035.

AMA. https://www.ama.org/the-definition-of-marketing-what-is-marketing/ (Erişim Tarihi: 11.10.2020).

Andaleeb, Syeed Saad; Basu, Amiya K. (1995). Explaining blood donation: the trust factor. Health Care Mark, $15,42-48$

Andreasen, Alan R. (1994). Social Marketing: Its Definition and Domain. Journal of Public Policy \& Marketing, 13(1), 108-114.

Argan, Mehpare T. (2016). Kan Bağış Davranışını Etkileyen Faktörlerin Planlı Davranış Teorisi Çerçevesinde İncelenmesi. ACU Sağllk Bil. Dergisi, 2, 96-104.

Armitage, Christoper. J.; Conner, Mark (2001). Efficacy of the theory of planned behavior: A meta-analytic review. British Journal of Social Psychology, 40, 471-499.

Armitage, Christoper. J.; Conner, Mark (2001). Social Cognitive Determinants of Blood Donation. Journal of Applied Social Psychology, Vol: 31, No: 7, 1431-1457.

Ayvaz, İbrahim; Torlak, Ömer (2016). Sosyal Pazarlama ve Ahlaki Boyutları. İş Ahlakı Dergisi, 9(2), 247 - 281.

Bagot, Kathleen L.; Masser, Barbara M. (2015). Using an Extended Theory of Planned Behavior to Predict a Change in the Type of Blood Product Donated. Annals of Behavioral Medicine, 49(4), 510-521.

Baron, R.A.; Byrne, D. (1977). Social Psychology: Underslanding Human Interaction, (2.ed), Boston: Allyn\&Bacon.

Bednall, Timothy C.; Liliana, Bove L.; Ali, Cheetham; Murray, Andrea, L. (2013). A systematic review and meta-analysis of antecedents of blood donation behavior and intentions. Social Science \& Medicine, 96, 86-94.

Beerli-Palacio, Asuncion; Martin-Santana, Josefa D. (2009). Model explaining the predisposition to donate blood from the social marketing perspective. International Journal of Nonprofit and Voluntary Sector Marketing, 14, 205-214.

Belda, Suarez; Fernández, Montoya; Fernández, Rodríguez; Berrio, López; Penuela, Cilero (2004). How regular blood donors explain their behavior. Transfusion, 44, 1441-1446.

Bloom, Paul N.; Yu Hussein, Pattie,; Szykman, Lissa R. (1995). Benefiting Society and The Bottom Line. Marketing Management, 14(3), 8-18.

Bodur, H. Onur; Brinberg, David; Coupey, Eloise (2000). Belief, Affect and Attitude: Alternative Models of The Determinants of Attitude. Journal of Consumer Psycholgy, 9(1), 17-28.

Bussell, H.; Forbes D. (2002). Understanding the Volunteer Market: The What, Where, Who and Why of Volunteering. International Journal of Nonprofit and Voluntary Sector Marketing, 7(3), 244-257.

Büyüköztürk, Ş. (2010). Sosyal Bilimler için Veri Analizi El Kitabı, Ankara: Pegem Yayıncılık.

Cüceloğlu, Doğan (2007). İnsan ve Davranışı. İstanbul: Remzi Kitabevi.

Davis, Kevin; Duke, Jennifer; Shafer, Paul; Patel, Deesha; Rodes, Robert; Beistle, Diane (2016). Perceived Effectiveness of Antismoking Ads and Association with Quit Attempts Among Smokers: Evidence from the Tips From Former Smokers Campaign. Health Communication, 32(8), 931-938.

Davis, Kevin; Uhrig, Jennifer; Bann, Carla; Doug, Rupert; Fraze, Jami (2011). Exploring African American Women's Perceptions of a Social Marketing Campaign to Promote HIV Testing. Social Marketing Quarterly, 17(3), 39-60.

Dann, Stephen (2010). Redefining social marketing with contemporary commercial marketing definitions. Journal of Business Research, 63, 147-153. 
Dillard, J. P.; Peck, E. (2000). Affect and persuasion: Emotional responses to public service announcements. Communication Research, 27, 461-495.

Dillard, J. P.; Shen, L.J.; Vail, R.G. (2007). Does perceived message effectiveness cause persuasion or vice versa? 17 consistent answers. Human Communication Research, 33, 467-488.

Echevarria, Covadonga. A.; Garcia, Maria S.A. (2014). A behavior model for blood donors and marketing strategies to retain and attract them. Rev. Latino-Am. Enfermagem, 22(3), 467-475.

Erdoğan, İrfan (1998). Araştırma Dizaynı ve İstatistiki Yöntemler, Ankara: Emel Matbaası.

Eser, Zeliha; Özdoğan, F. Bahar (2006). Sosyal Pazarlama. Ankara: Siyasal Kitabevi.

Faqah, Anadil; Moiz, Bushra; Shadid, Fatima; Ibrahim, Mariam; Rahiim, Ahmed (2015). Assessment of blood donation intention among medical students in Pakistan--An application of theory of planned behavior. Transfusion and Apheresis Science, 53, 353-359.

Ferguson, E. (1996). Predictors of future behaviour: A review of the psychological literature on blood donation. British Journal of Health Psychology,1, 287-308.

Ferguson, Eamonn; Atsma, Femke; Kort, Wim d; Veldhuizen, Ingrid (2012). Exploring the pattern of blood donor beliefs in first-time, novice, and experienced donors: differentiating reluctant altruism, pure altruism, impure altruism, and warm glow. Transfusion, 52, 343-355.

Fernández, Montoya; López-Berrio, A.; Luna Del Castillo, J.D. (1998). How some attitudes, beliefs and motivations of Spanish blood donors evolve overtime. Vox Sangninis, 74, 140-147.

France, Janis L.; Kowalsky, Jennifer M.; France, Cristpher R.; McGlone Sarah T.; Himawan, Lina K.; Kessler, Debra A.; Shaz, Beth H. (2014). Development of common metrics for donation attitude, subjective norm, perceived behavioral control, and intention for the blood donation context. Transfusion, 54, 837847.

France, Janis L.; France, Cristpher R.; Himawan, Lina K. (2007). A path analysis of intention to redonate among experienced blood donors: an extension of the theory of planned behavior. Transfusion, 47, 1006-1013.

Genç, Arda (2011). Sivil Toplum Kuruluşlarında Gönüllü Olma Güdüleri: Türk Kızılayı Eskişehir Şubesi Gönüllüleri Üzerine Bir Araştırma. Anadolu Üniversitesi SBE Yayımlanmamış Yüksek Lisans Tezi, Eskişehir.

Giles, M., Cairns, E. (1995). Blood donation and Ajzen's theory of planned behaviour: An examination of perceived behavioural control. British Jotirnal of Social Psychology, 34, 173-188.

Giles, M.; McClenahan, C.; Cairns, E.; Mallet, J. (2004). An application of the Theory of Planned Behaviour to blood donation: the importance of self-efficacy. Health Education Resarch, 19(4), 380-391.

Glynn, S.A.; Kleinman, S.H.; Schreiber, G.B.; Zuck, T.; Combs, S.M.; Bethel, J.; Garraty, G.; Williams, A.E. (2002). Motivations to donate blood; demographic comparisons. Transfusion, 42(2), 216-225.

Goldberg, M. E. (1995). Social marketing: are we fiddling while Rome burns. Journal of Consumer Psychology, $4(4), 347-370$.

Hablemitoğlu, Şengül; Özkan, Yasemin; Yıldırım, Filiz (2010). Bir Fedakâkarlık Örneği Olarak Kan Bağışı. Aile ve Toplum, Ocak-Şubat-Mart, 67-77.

Holdershaw, Judith; Gendall, Philip; Wright, Malcolm (2011). Predicting blood donation behaviour: further application of the theory of planned behaviour. Journal of Social Marketing, 1(2), 120-132.

İslamoğlu, Ahmet H.; Altunışık, Remzi (2013). Tüketici Davranışları. İstanbul: Beta.

Javadzadeh, Shahshahani H.; Yavari, M.T.; Attar, M.; Ahmadiyeh, M.H. (2006). Knowledge, attitude and practice study about blood donation in the urban poptilation of Yazd, Iran. Transfusion Medicine, 16, 403-409.

Kempf, DeAnna (1999). Attitude Formation from Product Trial: Distinct Roles of Cognition and Affect for Hedonic and Functional Product. Psycholgy and Marketing, 16(1), 35-50. 
Kocagöz, Elif; Dursun, Yunus (2010). Algılanan Davranışşal Kontrol, Ajzen'in Teorisinde Nasıl Konumlanır? Alternatif Model Analizleri. KMÜ Sosyal ve Ekonomik Araştırmalar Dergïi, 12(19), 139-152.

Kotler, P.; Andreasen, A. (1991). Strategie Marketing for Nonprofit Organizations, New Jersey:Prentice-Hall, Inc.

Kotler, P; Lee, N. (2010). Yoksulluğa Karşı Sosyal Pazarlama. (çev. Zeynep Kökkaya Chalar), İstanbul: MediaCat.

Kotler, P; Lee, N. (2007). Kamu Sektöründe Pazarlama: Kamu Kuruluşlarının Performansını Arttırmak için Bir Yol Haritası, (çev. Zeynep Kökkaya Chalar) İstanbul: MediaCat.

Kotler, P.; Zaltman, G. (1971). Social Marketing: An Approach to Planned Social Change. Journal of Marketing, 35(3), 3-12.

Ling, J. C.; Franklin, B. A.; Lindsteadt, J. F.; Gearon,S. A. (1992). Social marketing: its place in public health. Annual Review of Public Health, 13(1), 341-362.

Macfadyen, L.; Stead, M.; Hastıngs, G. (1999). A Synopsis of Social Marketing,http://staff.stir.ac.uk/w.m.thompson/Social\%20Enterprise/Library/Synopsis\%20of\%20Soci al\%20Marketing.pdf, (Erişim Tarihi: 14.07.2016).

Madden, T. J; Ellen, P.; Ajzen, I. (1992). A comparison of the theory of planned behavior and the theory of reasoned action. Personality and Social Psychology Bulletin, 18, 3-9.

Masser, Barbara M.; White, Katherine M.; Hyde, Melissa K.; Terry, Deborah; Robinson, Natalie G. (2009). Predicting blood donation intentions and behavior among Australian blood donors: testing an extended theory of planned behavior model. Transfusion, 49, 320-329.

McMahon, Roz; Bryne, Molly (2008). Predicting donation among an Irish sample of donors and nondonors: extending the theory of planned behavior. Transfusion, 48(2), 321-331.

Merav, Ben N.; Lena, Gorkov (2011). Investigating the factors affecting blood donation among Israelis. International Emergency Nursin, 19(1), 37-43.

Mirutse, Gabremeskel; Fisseha, Girmatsion; Abebe, Lakew; Birhanu, Zewda (2014). Intention to donate blood among the eligible population in Mekelle City, Northern Ethiopia: Using the theory of planned behavior. American Journal of Health Research, 2(4), 158-163.

Misje, A.H; Bosnes, V.; Gasdal, O.; Heier, H.E. (2005). Motivation, recruitment and retention of voluntary nonremunerated blood donors: a survey-based questionnaire study. Vox Sang, 89(4), 236-244.

Mucuk, İsmet (2014). Pazarlama İlkeleri. İstanbul: Türkmen.

Murphy-Hoefer, R.; Hyland, A.; Higbee, C. (2008). Perceived effectiveness of tobacco countermarketing advertisements among young adults. American Journal of Health Behavior, 32, 725-734.

Nakıboğlu, Burak; Özsoy, Tufan (2016). Sosyal Pazarlama: Sosyal Pazarlama Kampanyası Örnekleriyle. Ankara: Akademisyen Kitabevi.

Nonis, Sarath A.; Ford, Charles W.; Logan, Laddie; Hudson, Gail (1996). College Student's Blood Donation Behavior: Relationship to Demographics, Percieved Risk and Incentives. Health Marketing Quarterly, 13, 33-46.

Novatorov, E.V; Crompton, J.L. (2001). A Revised Conceptualization of Marketing in the Context of Public Leisure Services. Journal of Leisure Research, 33(2), 169-186.

Odabaşı, Yavuz; Barış, Gülfidan (2010). Tüketici Davranışı, İstanbul: MediaCat.

Ownby, H.E.; Kong, F.; Watanahe, K.; TU, Y.; Nass, C.C. (1999). Analysis of donor return behaviour. Retrovirus Epidemiology Donor Study. Transfusion, 39, 128-135.

Özdamar, Kazım (1999). Paket Programlar İle İstatistiksel Veri Analizi. Eskişehir: Kaan Kitabevi.

Özsoy, Tufan (2015). Teknoloji Bazlı Pazarlama Uygulamalarının Sosyal Pazarlama'da Kullanılmasına Yönelik Bir Model Önerisi. 20. Ulusal Pazarlama Kongresi, (Eskişehir-Türkiye 2015). 
Öztürk, Abdülkadir; Nart, Sima; Altunışık, Remzi (2015). Tüketicilerin Helal Tüketim Davranışlarının Belirleyicileri: Planlı Davranış Teorisi Çerçevesinde Bir Araştırma. International Journal of Islamic Economics and Finance Studies, 1(2), 141-160.

Özgül, Engin (2010). Tüketicilerin Değer Yapıları, Gönüllü Sade Yaşam Tarzı ve Sürdürülebilir Tüketim Üzerindeki Etkileri. Hacettepe Üniversitesi İ̈BF Dergisi, 28(2), 117-150.

Pagliariccio A; Guermandi, G.; Marinozzi, M.; Piani, M.(2003). Can better information increase hemapheresis. Transfusion and Apheresis Science, 28, 149-153.

Peattie, Ken; Peattie, Sue (2009). Social marketing: A pathway to consumption reduction. Journal of Business Research, 62(2), 260-268.

Peattie, Ken; v, Sue (2003). Ready to Fly Solo? Reducing Social Marketing's Dependence on Commercial Marketing Theory. Marketing Theory, 3(3) 365-86.

Petty, R.E.; Caciopo, J.T. (1986). The elaboration likelihood model of persuasion. Advances in Experimental Social Psychology, 19, 123-205.

Raftopoulou, Christina-Effimia (2011). "The Captured Citizen: A Critique Of Social Marketing",https://www.mngt.waikato.ac.nz/ejrot/cmsconference/2003/proceedings/criticalmarketin g/Reftopoulou.pdf, (Erişim Tarihi: 06.03.2018).

Rothschild, M. (1997). An Historic Perspective of Social Marketing. Journal of Health Communication, 2, 308-309.

Schuster, Lisa; Kubacki, Krzysztof; Rundle-Thiele, Sharyn (2016). Community-based social marketing: effects on social norms. Journal of Social Marketing, 6(2), 193-210.

Shove, E. (2010). Beyond the ABC: Climate Change Policy and Theories of Social Change. Environment and Planning, 42(6), 1273-1285.

Sümer, Nebi (2000). Yapısal Eşitlik Modelleri: Temel Kavramlar ve Örnek Uygulamalar. Türk Psikoloji Yazıları, $3(6), 49-74$

Tek, Ömer Baybars; ÖZGÜL, Engin (2013). Modern Pazarlama İlkeleri: Uygulamah Yönetimsel Yaklaşım. İzmir: Birleşik Matbaacılık.

Tekeş, Burcu; Hasta, Derya (2015). Özgecilik Ölçeği: Geçerlik ve Güvenirlik Çalışması. Nesne Psikoloji Dergisi, $3(6), 55-75$

Torlak, Ömer (2007). Pazarlama Ahlakı: Sosyal Sorumluluk Ekseninde Pazarlama Kararları ve Tüketici Davranışlarının Analizi. Pazarlama Dünyası, İstanbul: Beta.

Trimmel, Michael; Lattacher, Helene; Janda, Monika (2005). Voluntary whole-blood donors, and compensated platelet donors and plasma donors: Motivation to donate, altruism and aggression. Transfusion and Apheresis Science, 33, 147-155.

TUIK. http://www.tuik.gov.tr/ustmenu.do?metod=temelist (Erişim Tarihi: 05.05.2017).

Wildman, John; Hollingsworth, Bruce (2009). Blood donation and the nature of altruism. Journal of Health Economics, 28, 492-503.

Zaller N; Nelson, K.E.; Ness, P.; Wen, G.; Bai, X.; Shan, H. (2005). Knowledge, attitude and practice survey regarding blood donation in a Northwestern Chinese city. Transfusion Medicine, 15, 277-286. 